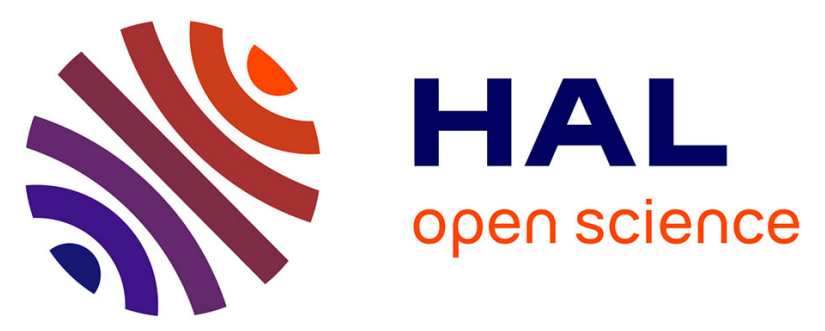

\title{
Integrated multi-stratigraphic study of the Coll de Terrers late Permian-Early Triassic continental succession from the Catalan Pyrenees (NE Iberian Peninsula): A geologic reference record for equatorial Pangaea
}

Eudald Mujal, Josep Fortuny, Jordi Pérez-Cano, Jaume Dinarès-Turell, Jordi Ibáñez-Insa, Oriol Oms, Isabel Vila, Arnau Bolet, Pere Anadón

\section{- To cite this version:}

Eudald Mujal, Josep Fortuny, Jordi Pérez-Cano, Jaume Dinarès-Turell, Jordi Ibáñez-Insa, et al.. Integrated multi-stratigraphic study of the Coll de Terrers late Permian-Early Triassic continental succession from the Catalan Pyrenees (NE Iberian Peninsula): A geologic reference record for equatorial Pangaea. Global and Planetary Change, 2017, 159, pp.46-60. 10.1016/j.gloplacha.2017.10.004 . hal-01724348

\section{HAL Id: hal-01724348 \\ https: / hal.sorbonne-universite.fr/hal-01724348}

Submitted on 6 Mar 2018

HAL is a multi-disciplinary open access archive for the deposit and dissemination of scientific research documents, whether they are published or not. The documents may come from teaching and research institutions in France or abroad, or from public or private research centers.
L'archive ouverte pluridisciplinaire HAL, est destinée au dépôt et à la diffusion de documents scientifiques de niveau recherche, publiés ou non, émanant des établissements d'enseignement et de recherche français ou étrangers, des laboratoires publics ou privés. 


\title{
Integrated multi-stratigraphic study of the Coll de Terrers late Permian-Early Triassic continental succession from the Catalan Pyrenees (NE Iberian Peninsula): A geologic reference record for equatorial Pangaea
}

\author{
Eudald Mujal $^{\mathrm{a}, \mathrm{c}, *}$, Josep Fortuny ${ }^{\mathrm{b}, \mathrm{c}}$, Jordi Pérez-Cano ${ }^{\mathrm{a}, \mathrm{f}}$, Jaume Dinarès-Turell $^{\mathrm{d}}$, \\ Jordi Ibáñez-Insa ${ }^{\mathrm{e}}$, Oriol Oms ${ }^{\mathrm{a}}$, Isabel Vila ${ }^{\mathrm{f}}$, Arnau Bolet ${ }^{\mathrm{c}}$, Pere Anadón ${ }^{\mathrm{e}}$ \\ a Departament de Geologia, Universitat Autònoma de Barcelona, E-08193 Bellaterra, Spain \\ b Centre de Recherches en Paléobiodiversité et Paléoenvironnements, UMR 7202 CNRS-MNHN-UPMC, Muséum national d'Histoire naturelle, Bâtiment de Paléontologie, 8 \\ rue Buffon, CP38, F-75005 Paris, France \\ ${ }^{c}$ Institut Català de Paleontologia Miquel Crusafont, ICTA-ICP building, c/de les columnes, $s / n$, E-08193 Cerdanyola del Vallès, Spain \\ ' Istituto Nazionale di Geofisica e Vulcanologia, Via di Vigna Murata 605, I-00143 Roma, Italy \\ e Institut de Ciències de la Terra Jaume Almera, ICTJA-CSIC, c/Lluís Solé i Sabarís s/n, E-08028 Barcelona, Spain \\ ${ }^{\mathrm{f}}$ Departament de Dinàmica de la Terra i de l'Oceà (Facultat de Geologia), Universitat de Barcelona, c/Martí i Franquès $s / n$, E-08028 Barcelona, Spain
}

\section{A R T I C L E I N F O}

\section{Keywords:}

Permian-Triassic transition

Stratigraphy

Orbital forcing

X-ray diffraction

Tetrapod footprints

Western Tethys

\begin{abstract}
A B S T R A C T
The most severe biotic crisis on Earth history occurred during the Permian-Triassic (PT) transition around $252 \mathrm{Ma}$. Whereas in the marine realm such extinction event is well-constrained, in terrestrial settings it is still poorly known, mainly due to the lack of suitable complete sections. This is utterly the case along the Western Tethys region, located at Pangaea's equator, where terrestrial successions are typically build-up of red beds often characterised by a significant erosive gap at the base of the Triassic strata. Henceforth, documenting potentially complete terrestrial successions along the PT transition becomes fundamental. Here, we document the exceptional Coll de Terrers area from the Catalan Pyrenees (NE Iberian Peninsula), for which a multidisciplinary research is conducted along the PT transition. The red-bed succession, located in a long $E$-W extended narrow rift system known as Pyrenean Basin, resulted from a continuous sedimentary deposition evolving from meandering (lower Upper Red Unit) to playa-lake/ephemeral lacustrine (upper Upper Red Unit) and again to meandering settings (Buntsandstein facies). Sedimentary continuity is suggested by preliminary cyclostratigraphic analysis that warrants further analysis. Our combined sedimentological, mineralogical and geochemical data infer a humid-semiarid-humid climatic trend across the studied succession. The uppermost Permian strata, deposited under an orbitally controlled monsoonal regime, yields a relatively diverse ichnoassemblage mainly composed of tetrapod footprints and arthropod trace fossils. Such fossils indicate appropriate life conditions and water presence in levels that also display desiccation structures. These levels alternate with barren intervals formed under dry conditions, being thus indicative of strong seasonality. All these features are correlated with those reported elsewhere in Gondwana and Laurasia, and suggest that the Permian-Triassic boundary might be recorded somewhere around the Buntsandstein base. Consequently, Coll de Terrers and the whole Catalan Pyrenees become key regions to investigate in detail the Permian extinction event and the Triassic ecosystems recovery.
\end{abstract}

\section{Introduction}

The Permian and Triassic periods are characterised by large continental landmasses resulting from the formation of Pangaea, which enhanced global aridity and red-beds deposits (Gibbs et al., 2002; Chumakov and Zharkov, 2003; Roscher and Schneider, 2006; Schneider et al., 2006; Looy et al., 2016; Kustatscher et al., 2017). The
Permian-Triassic record has been largely studied, mostly with the aim of unravelling the events that triggered the major biological crisis of Earth's history, i.e., the end-Permian mass extinction (Erwin, 1994). Such event is now well-documented in the marine realm (Payne and Clapham, 2012), but questions still remain open in the case of the continental record (Gastaldo et al., 2015; Chu et al., 2016; Zhang et al., 2016). Benton and Newell (2014) have recently considered several key

\footnotetext{
* Corresponding author.

E-mail addresses: eudald.mujal@gmail.com (E. Mujal), josep.fortuny@icp.cat (J.Fortuny), jordi_perez-cano@ub.edu (J. Pérez-Cano), jaume.dinares@ingv.it (J. Dinarès-Turell), jibanez@ictja.csic.es (J. Ibáñez-Insa), joseporiol.oms@uab.cat (O. Oms), ivilapla7@alumnes.ub.edu (I. Vila), arnau.bolet@icp.cat (A. Bolet), panadon@ictja.csic.es (P. Anadón).
} 
zones to study both the Permian-Triassic continental record and the Permian-Triassic boundary (PTB), including Western and Central Europe, Russia and Siberia, central India, South China, central-eastern South America, South Africa, Australia and Antarctica. In addition, recent works provided new data to characterise the Permian-Triassic transition in terrestrial successions from Central Germany (Scholze et al., 2017) and South China (Chu et al., 2016; Zhang et al., 2016; Xu et al., 2017). In general, Western Europe successions (Western periTethyan domain) are characterised by an important erosive contact around the PTB (Bourquin et al., 2007, 2011). Recent works have attempted to constrain the Permian-Triassic transition and quantify the lack of record in the case of the Catalan Pyrenees (NE Iberian Peninsula), where long continental successions ranging from the late Carboniferous to the Middle Triassic are known to exist (Gretter et al., 2015; Mujal et al., 2016a). Thus, despite the continental Western periTethyan regions are deeply studied, continuous terrestrial Permian-Triassic sections are hardly identified (Bourquin et al., 2011; Kustatscher et al., 2017).

In the present work we introduce and characterise a new section from the Catalan Pyrenees spanning from the uppermost Permian to the lowermost Triassic record. The multidisciplinary study performed on this section includes lithostratigraphy, sedimentology, cyclostratigraphy, mineralogy (X-ray diffraction, XRD), geochemistry (X-ray fluorescence, XRF) and palaeontology (tetrapod and invertebrate ichnology), as well as palaeomagnetism (magnetostratigraphy). Based on our analyses, this section is free from the Triassic erosive gap, so it is a prospective area to identify the PTB in a continental succession of the Western peri-Tethyan domain, in equatorial Pangaea (Fig. 1A).

\section{Geological setting}

During the late Palaeozoic and early Mesozoic, the Iberian microplate was located in the equatorial latitudes of Pangaea, in the Western peri-Tethyan region, at the confluence of Gondwana and Laurasia landmasses (Dercourt et al., 2000; Fig. 1A). The microplate rotation at that time generated the extensional (rifting) Iberian, Catalan and Pyrenean basins (De la Horra et al., 2012). The present-day Pyrenean range (located at the NE Iberian Peninsula and originated during the Alpine orogeny; Fig. 1B) was formerly composed of continental sedimentary basins controlled by a transtensional tectonic activity (Speksnijder, 1985; Saura and Teixell, 2006; Gretter et al., 2015). Pyrenean basins accumulated sediments from the late Carboniferous to the Middle Triassic because of the erosion of the Variscan orogen and the associated volcanic episodes (Gisbert, 1981; Martí, 1983; Gisbert et al., 1985; Pereira et al., 2014), related to the breakup of Pangaea (Torsvik and Cocks, 2013). The lithostratigraphic record was defined by Mey et al. (1968) and Nagtegaal (1969), while Gisbert (1981) established the depositional units here used (Fig. 1C). These units are, from base to top: Grey Unit (GU), Transition Unit (TU), Lower Red Unit (LRU), Upper Red Unit (URU) and Buntsandstein facies unit.

The present work is focused in the red-beds of the URU and its transition to the Buntsandstein facies unit, corresponding to the uppermost Permian and the lowermost Triassic Pyrenean record, respectively (Mujal et al., 2016a). Whereas the Buntsandstein facies is found along the entire Catalan Pyrenees, the URU is only recorded in the eastern part, in the Cadí sub-basin (Gisbert, 1981; Speksnijder, 1985). Here we divide the Upper Red Unit in two parts or subunits: lower URU and upper URU. This is because we have found that two different palaeoenvironmental settings can be well-differentiated in the URU (see Section 4.1 below; Fig. 2A, B). The lower URU is mainly composed of breccias, conglomerates, sandstones and red mudstones with limestone nodules, whereas the upper URU is build-up of red mudstones alternated with thin-bedded and fine-grained sandstone layers constituting metre-scale cyclic sequences (see sections 4.1 and 4.2 below). Due to the basin configuration, the URU is found above an angular unconformity developed on the top of the Variscan basement (Mujal et al., 2017) or the early Permian LRU (Gisbert et al., 1985; Speksnijder, 1985; Gretter et al., 2015). The Triassic Buntsandstein facies are generally of alluvial origin and are composed of basal breccias and conglomerates, followed by a succession of sandstones and red mudstones,
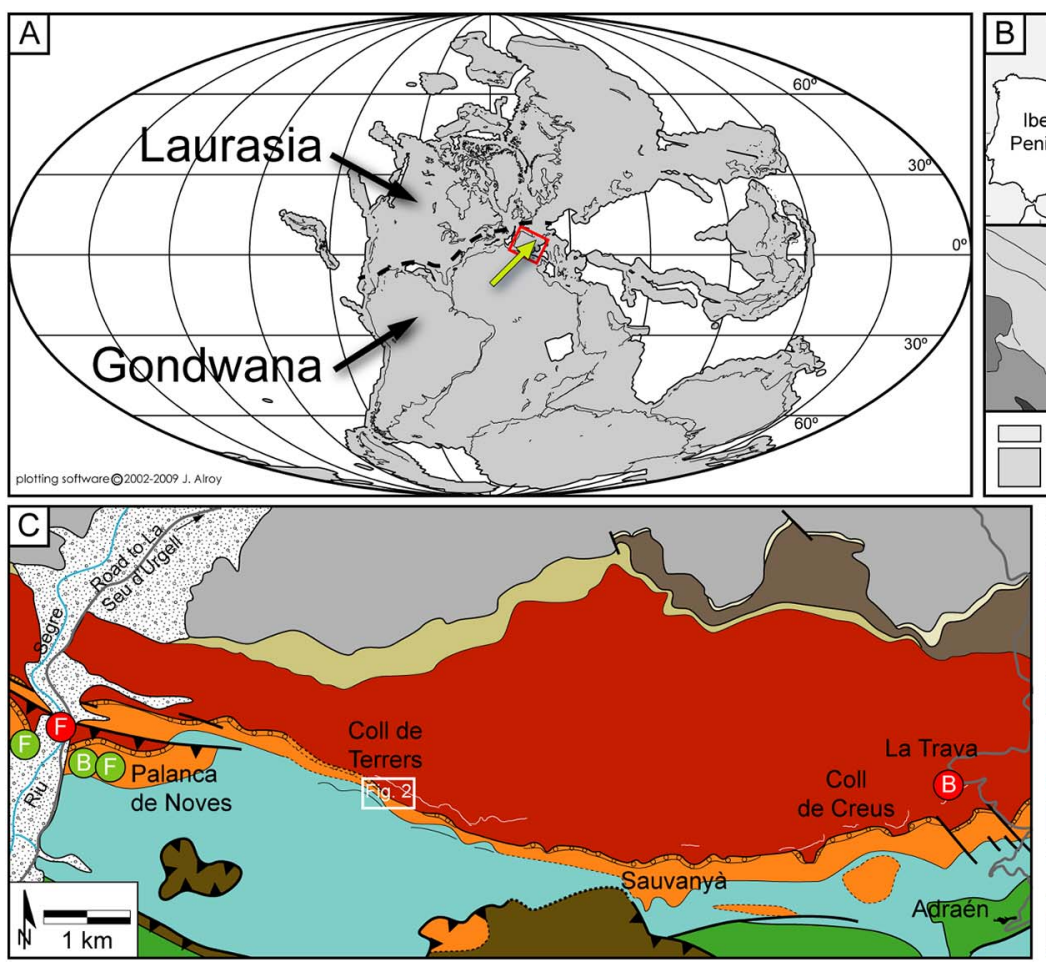

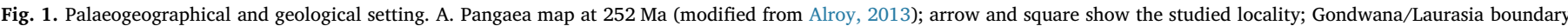

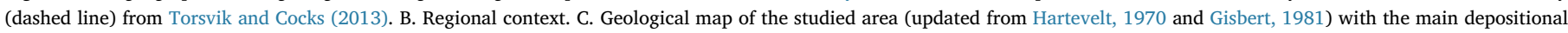
units and equivalent lithostratigraphic formations; dashed lines correspond to uncertain contacts.

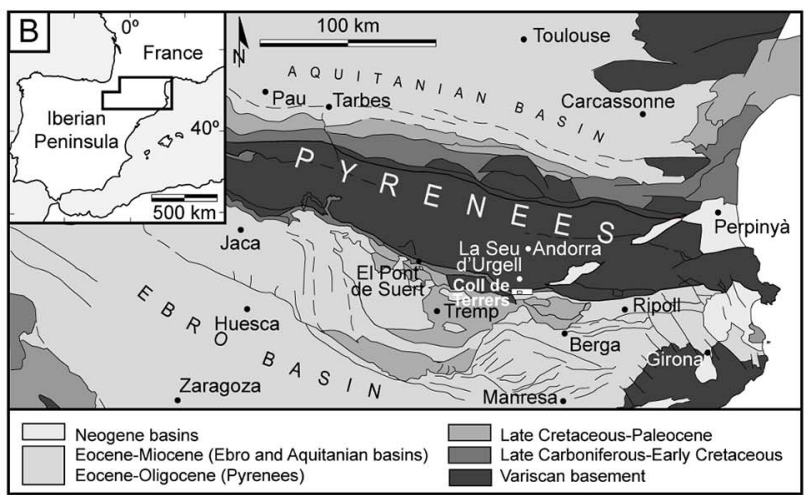

Quaternary alluvial deposits

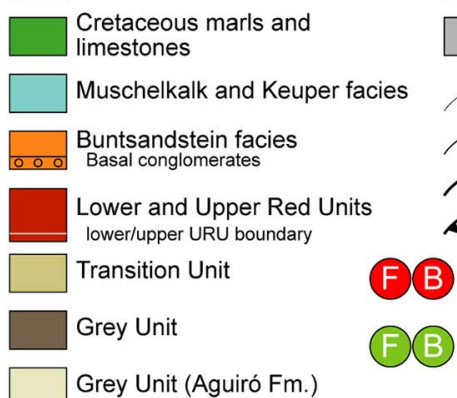

Devonian basement

Cambroordovician basement

Concordant contact Unconformity Fault Thrust Permian (URU) tetrapod footprints and bone Triassic (Buntsandstein) tetrapod footprints and bones 

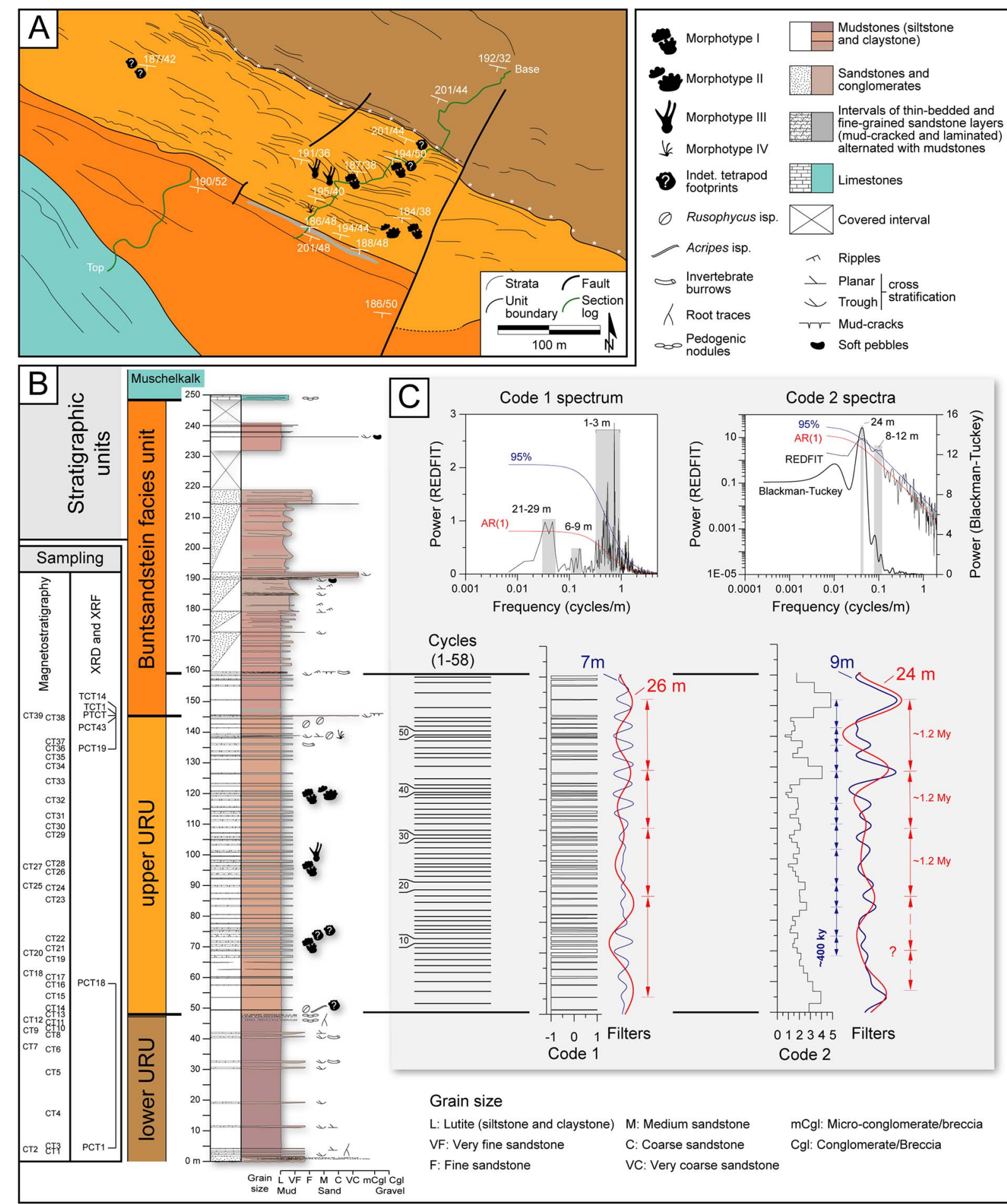

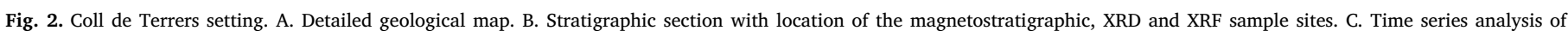

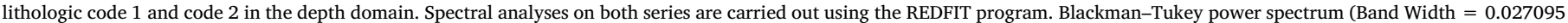

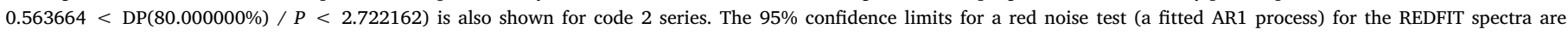

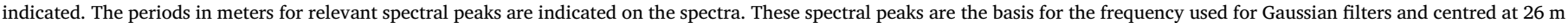

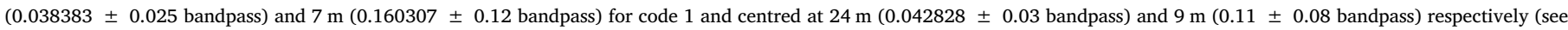
text for discussion).

and finally by a red mudstone interval (Gisbert et al., 1985). The Buntsandstein unit is overlaid by the marlstone-limestone succession of the Muschelkalk and Keuper facies deposited during the Middle Triassic transgression. Basin palaeorelief controlled changes in thickness and lateral facies changes of both URU and Buntsandstein.

The URU/Buntsandstein boundary is commonly an angular unconformity (Gisbert et al., 1985; Gretter et al., 2015; Mujal et al., 2016a, 2017), as also occur in the other Permian-Triassic Iberian basins (Borruel-Abadía et al., 2015) and generally in the whole Western Europe (Bourquin et al., 2011). This is not the case of the Coll de Terrers area (Alt Urgell, Catalonia, NE Iberian Peninsula; Fig. 1B, C), where a conformable succession between the Permian and Triassic 

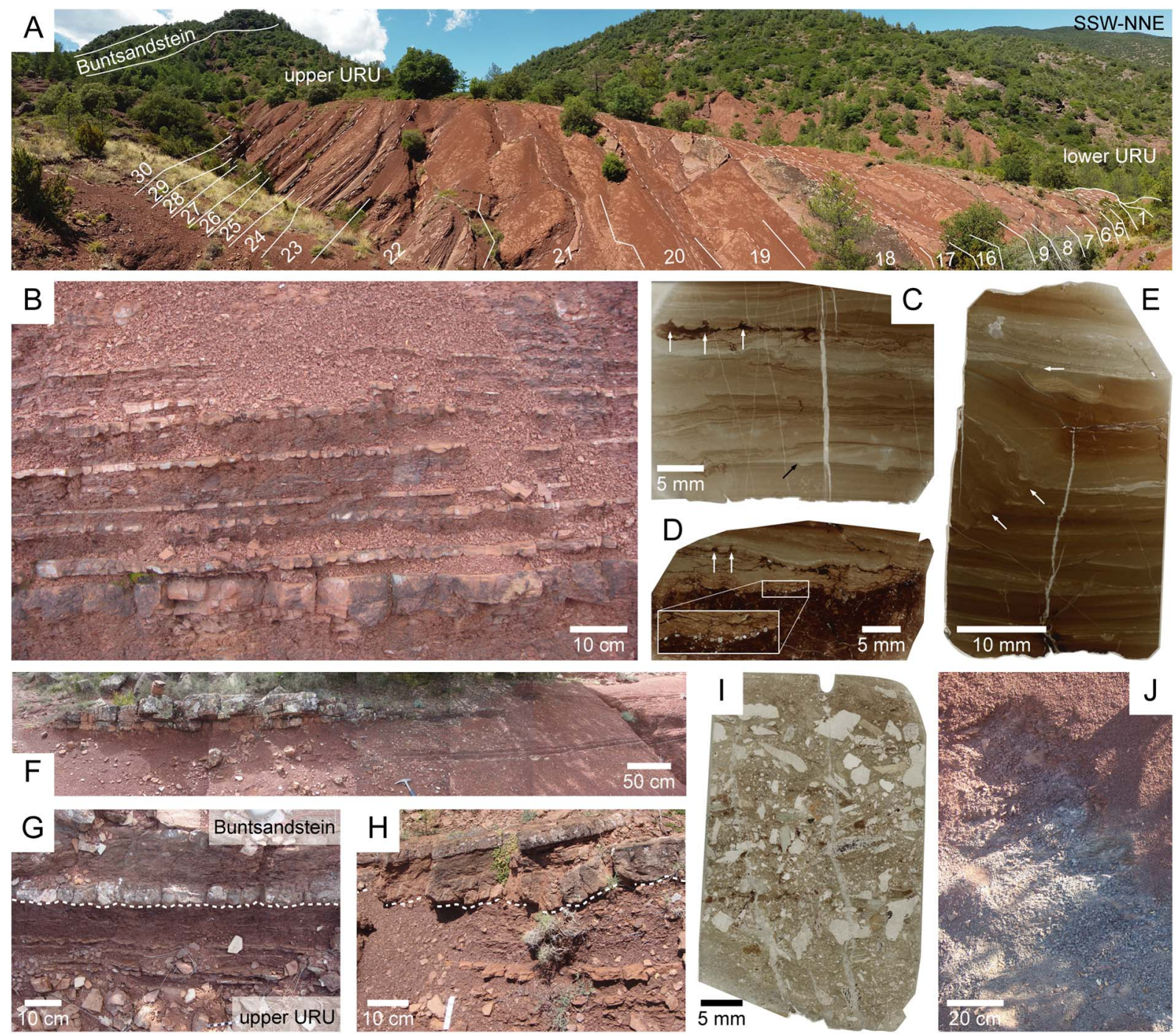

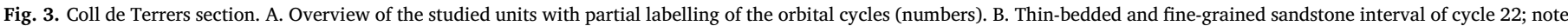

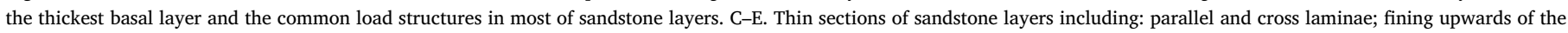

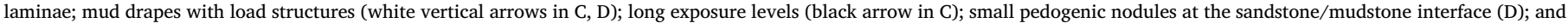

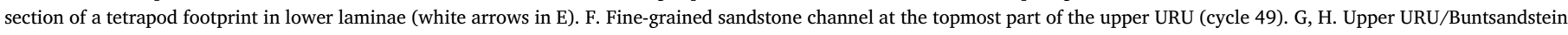

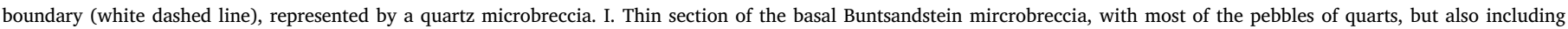
feldspars. J. Grey mudstone interval at the base of the Buntsandstein facies and overlying red mudstones.

strata is observed (Fig. 2; see Section 4 below).

\section{Methods}

The studied section is $250 \mathrm{~m}$ thick and is located in coordinates WGS84 UTM $31 \mathrm{~N}$ 369341E, 4,682,768 N (base) and 368925E, 4,682,570 N (top). It contains three lithologic units: lower URU, upper URU and Buntsandstein facies that were measured by means of a Jacobs staff and a metre (Fig. 2B); a detailed geological map was also carried out (Fig. 2A). To assist sedimentological determinations, analyses were performed through field observations and thin sections ( $30 \mu \mathrm{m}$ thick) obtained from 16 rock samples. The magnetostratigraphic study consisted in the analyses of samples distributed in 39 sites along the URU (Fig. 2B). However, it was found that the succession does not preserve a primary magnetism but, rather, a pervasive remagnetization. Methods, results and discussion of the palaeomagnetic data are provided as Supplementary Data (Text S1).

The lithologic succession of the upper URU and lowermost Buntsandstein has been codified to make it amenable to spectral analysis in order to explore its cyclic nature (Fig. 2C). Two approaches have been applied. The first one (code 1 ) assigns either 1 or -1 to the respective red mudstones or thin-bedded sandstone layers constituting the basic sequences. The second approach (code 2) assigns the stratigraphic thickness of the sequence throughout the encompassed interval of such sequence. The codified series at $2 \mathrm{~cm}$ resolution were used for spectral analysis. The Blackman-Tuckey method implemented in the AnalySeries v.2 software package (Paillard et al., 1996) and the REDFIT program (Schulz and Mudelsee, 2002) were employed. AnalySeries was further used for filtering the time series.

After preliminary prospective mineralogical and elemental analysis by XRD and XRF, sampling was mainly focused on the transition between the three units in order to identify any mineralogical variation. Sampling of lower and upper URU and Buntsandstein accounted for 15, 44 and 15 samples, respectively (Fig. 2B).

For the XRD measurements the samples were pulverised and homogenised to produce randomly-oriented powders. XRD scans were acquired between $4^{\circ}$ and $65^{\circ}$ in $2 \theta\left(0.02^{\circ}\right.$ per step $)$ by using a Bruker D8-A25 diffractometer equipped with a $\mathrm{Cu} \mathrm{X}$-ray source ( $\mathrm{CuK} \alpha$ radiation) and a LynxEye position sensitive detector. Phase identification was performed by using the DIFFRAC.EVA software together with the 
Powder Diffraction File PDF-2 and the Crystallography Open Database (COD). Semi-quantitative phase analyses (SQPA) were carried out by using Reference Intensity Ratio (RIR) values for each of the identified phases.

The elemental composition of the samples was investigated by XRF measurements. For this purpose, a Bruker Tracer IV-Geo energy-dispersive XRF analyser equipped with a large area $\left(30 \mathrm{~mm}^{2}\right)$ silicon drift detector and a $40 \mathrm{kV}$ Rh X-ray tube was employed. For each sample, two different XRF scans were obtained: one measurement excited with low voltage $(15 \mathrm{keV})$ to optimize the detection of light elements (13 $<Z \leq 28)$, and a second measurement excited with large voltages $(40 \mathrm{keV})$ to detect heavier elements $(Z>28)$.

A palaeontological prospection was also carried out. Tetrapod footprints and invertebrate trace fossils were found and studied in situ, documented through photographs and schemes (processed in a vector based software), and situated in the measured section and in the geological map (Fig. 2A, B). Tetrapod footprints were analysed following the methods of Leonardi (1987). Additionally, seven 3D photogrammetric models were performed from selected specimens (including manus-pes sets and isolated ichnites). Photographs were obtained with a digital compact camera Sony DSC-T200 8.1 Megapixel and processed using open access software following the methods of Mujal et al. (2016b): Visual SFM v.0.5.24 (http://www.ccwu.me/vsfm/; to obtain the point cloud), MeshLab v.1.3.2 (http://meshlab.sourceforge.net; to create, scale and orientate the 3D mesh), and ParaView v.4.1.0 (http:// www.paraview.org; to create the colour depth maps and contour lines). An ex situ slab bearing small tetrapod footprints was collected and is stored at Institut Català de Paleontologia Miquel Crusafont (Sabadell, Catalonia, Spain) and labelled as IPS-99097.

\section{Coll de Terrers section: Results and interpretation}

The analysed Coll de Terrers section (Cadí sub-basin of the Pyrenean rift system) is a red bed succession dipping south-westwards. The three units of the succession (lower URU, upper URU and Buntsandstein facies; Figs. 2, 3) correspond to three different sedimentary settings. In the following sections we present and interpret the detailed lithologic frame of the three units and the analytic and palaeontological data.

\subsection{Stratigraphy and sedimentology}

The Coll de Terrers deposits represent tectonically controlled sequences (Gisbert et al., 1985; Speksnijder, 1985; Gretter et al., 2015). At Coll de Terrers, the URU overlays in angular unconformity the Lower Red Unit (LRU), which corresponds to a red-beds succession of volcanosedimentary origin of early Permian age (Pereira et al., 2014; Mujal et al., 2016b). Out from Coll de Terrers, the basal portion of the lower URU (here not studied) is composed of polymictic conglomerates and breccias with coarse sandstone matrix corresponding to alluvial braided facies (Gisbert, 1981; Gretter et al., 2015).

These coarse deposits are covered by fine- to medium-grained sandstones with occasional microconglomeratic levels, plant fragments and root traces (base of the measured section; Fig. S1). Sandstones rapidly grade to wine-red mudstones with occasional fine- to mediumgrained sandstone body channels with lateral accretions and cross stratifications, of low lateral continuity and with sporadic vertical and tubular invertebrate burrows (Fig. S1). Some mudstone intervals exhibit pedogenic carbonate nodules with diameters ranging from millimetre up to $1 \mathrm{~cm}$. The whole interval, of $45.5 \mathrm{~m}$ in the measured section (Fig. 2), is interpreted as corresponding to distal meandering fluvial (sandstone bodies) and floodplain systems (mudstone intervals), where palaeosol levels were developed (Gisbert, 1981; Gretter et al., 2015).

The lower/upper URU boundary is represented by three levels of large carbonate nodules (up to $15 \mathrm{~cm}$ of diameter) generally septariform (i.e., radial and concentric networks of cracks filled with calcite; Fig. S2). The mudstones just below the boundary display vertical and sinuous greenish reduction marks corresponding to root traces as well as slickensides (Fig. S2C). Mudstone intervals as those of the lower URU separate the nodular levels, with a total thickness of $2 \mathrm{~m}$ in average. These nodules indicate long periods of pedogenesis, where palaeosols were well-developed. Such boundary can be observed and traced along almost $7 \mathrm{~km}$ (Fig. 1C), dividing the URU in two sequences of different depositional settings.

The overlying upper URU deposits (Fig. 3) are $97.3 \mathrm{~m}$ thick in the measured section. They build up a cyclic or rhythmic sequence of redorange mudstones alternated with 54 thin-bedded and fine-grained sandstone intervals (Figs. 2, 3A). Thickness of the mudstone intervals oscillates from 0.2 to $6.2 \mathrm{~m}$ along the succession, with an average of $1.5 \mathrm{~m}$. Occasionally, the red-orange mudstones preserve small nodules mostly accumulated in the interface with the fine-grained sandstone layers (Fig. 3D). The thin-bedded and fine-grained sandstone intervals range from $0.03 \mathrm{~m}$ to $0.8 \mathrm{~m}$ thick (average of $0.38 \mathrm{~m}$ ). These intervals consist of laminated layers around $2-5 \mathrm{~cm}$ thick (and up to $15 \mathrm{~cm}$ thick) alternated with $2-3 \mathrm{~cm}$ thick mudstone layers (Fig. 3B). Sandstone layers are orange-brownish and occasionally greenish-greyish. The number of thin-bedded sandstone layers in each interval oscillates from 1 to 15 , but they commonly contain 6-7 layers.

These alternating intervals are of long lateral continuity $(\sim 450 \mathrm{~m}$ observed, which is the lateral extension of the outcrop; Figs. 2, 3A). Within each interval, the basal sandstone layer is thicker $(5-10 \mathrm{~cm}$, up to $15 \mathrm{~cm})$ than the rest $(2-5 \mathrm{~cm}$ in average). The lower boundary of some basal sandstone layers is transitional. Layers decrease in thickness and lateral continuity to the top, building up thinning and fining upwards sequences (Fig. 3B). The lower half of the layers is generally irregular due to load structures (flames, balls and pillows; Fig. 3B, C). The uppermost surface of all layers is mud-cracked, sometimes preserving ripple marks. In some cases, two periods of desiccation are observed in each layer: the lower half presents a genesis of mud-cracks not expressed in the upper half, which shows a second genesis. Laminations are either parallel (building up fining upwards sequences), or cross laminated (with flow and wave ripples) (Fig. 3C-E). Thin sections reveal thin mud drapes covering laminae (Fig. 3C, D). Laminae overlying mud drapes often present load structures (Fig. 3C). Towards the top of the upper URU (138-139 m of the measured section) we observed fine- to medium-grained and cross-stratified sandstone channels, 0.5 to $3 \mathrm{~m}$ long and up to $30 \mathrm{~cm}$ thick, and laterally changing to the thin-bedded and fine-grained sandstone layers (Fig. 3F). The presence of mud drapes within laminated sandstones, the long lateral continuity of sandstone layers and the lack of major erosive structures within this succession indicate that the upper URU most probably does not present gaps of record.

Tetrapod footprints (see Section 4.4.1 below) are mostly found in the basal sandstone layers, which provide extensive outcropping surfaces. Some small footprints are found in layers above the basal one (in some cases observed in cross section). In a particular case, the lower half of a layer preserved a tetrapod footprint covered by the uppermost laminae (Fig. 3E). Invertebrate trace fossils with tiny, well-defined features (see Section 4.4.2 below) are also found in the fine-grained sandstone layers, usually preserved as casts.

The whole set of sedimentary structures suggests a relatively dry setting if compared with the lower URU. The upper URU is here interpreted as a distal alluvial plain system (fan fringe/playa-lake, or ephemeral lacustrine). The muddy portions of the succession would indicate conditions of low or absent stagnant water in the depositional environment. In contrast, the relatively coarser intervals (i.e., the 54 intervals of thin-bedded and fine-grained sandstone layers) would represent conditions of more persistent stable water within a complexivelly arid climate.

Such duality of environments has been recorded as a monsoonal system related to the formation of Pangaea (Parrish and Peterson, 1988; Kutzbach and Ziegler, 1993; Roscher and Schneider, 2006; Roscher et al., 2011; Tabor et al., 2011) established in the equatorial region 
since the early Permian (Tabor and Montanez, 2002). Therefore, the thin-bedded sandstone layers would correlate with maximum monsoonal periods and the thick mudstone intervals would correlate with periods of reduced monsoonal activity. Similar monsoonal systems are those of the Salagou formation from the French Lodève Basin (Roscher and Schneider, 2006; Schneider et al., 2006), although these deposits have recently been dated as early-middle Permian (Michel et al., 2015).

The overlying Buntsandstein succession is $103 \mathrm{~m}$ thick, being one of the thinnest observed in the Catalan Pyrenees. The base of the Buntsandstein is represented by a 20 to $50 \mathrm{~cm}$ thick microbreccia of quartz pebbles with subordinated feldspar and lithics, and a matrix of red coarse-grained sandstones and mudstones (Fig. 3G-I). It is slightly erosive, and the topmost portion is composed of fine- to very finegrained laminated sandstone, which is mud-cracked. The composition of this microbreccia is equivalent to that of the Buntsandstein basal conglomerates from other Pyrenean regions (e.g., Gretter et al., 2015; Mujal et al., 2017; Fig. 3I), and can be traced laterally to the welldeveloped conglomeratic sequences (Figs. 1, 2). This microbreccia conformably overlies (i.e., strike and dip angles are the same) a finegrained sandstone interval of six layers from the upper URU (Fig. 3G, H).

The basal microbreccia is overlaid by a $13.5 \mathrm{~m}$ thick sequence composed of red mudstones, with a $1 \mathrm{~m}$ thick grey interval at the lower part (at $146.7-147.7 \mathrm{~m}$ in the measured section; Fig. $3 \mathrm{~J}$ ). Four laterally continuous intervals of thin-bedded and fine-grained sandstone layers as those of the upper URU are found in the red mudstones above the grey interval. Despite slight differences in colour and composition (see Section 4.3 below) this interval also displays the cyclicity observed in the upper URU attributed to the monsoonal recurrence, thus indicating a continuous sedimentation, in the same depositional setting, from the upper URU to the Buntsandstein facies unit.

The successive interval consists of fine- to medium-grained channelized sandstones with trough and planar cross stratifications, ripples and other flow structures, as well as vertical burrows; thin conglomeratic layers (10-30 cm thick) occasionally constitute the base of the sandstone bodies (lag deposits). These bodies build up fining-upwards sequences, and often grade to metric red mudstone intervals with occasional carbonate nodules of pedogenic origin (Fig. 2). These facies are interpreted as alluvial fans with braided systems evolving to meandering and floodplain settings. The carbonate-dominated Muschelkalk facies, resulting from the Middle Triassic marine transgression, cover the Buntsandstein deposits.

\subsection{Cyclostratigraphy}

The upper URU and the first $13.5 \mathrm{~m}$ of the Buntsandstein facies are built up of alternating mudstones and thin-bedded sandstone intervals with a cyclic stacking pattern. We have defined the basic sequences or cycles to include two half muddy parts and the interbedded interval with sandstone layers (i.e., sandstones interpreted to represent the maximum enhanced monsoonal periods). Thus, a basic sequence starts and finishes in the middle of the relatively thick muddy interval layers representing periods of reduced monsoonal action. The total number of sequences is 58: $53-54$ at the upper URU and 4-5 at the Buntsandstein facies, where sequence 54 starts in the upper URU and finishes in the Buntsandstein. Spectral analysis of the code 1 time series in the depth domain (Fig. 2C) displays significant peaks in a band including periods in the range 1-3 m, which correspond to the main thickness of the basic sequences. Other peaks which are not found to be significant are located in bands corresponding to periods of 6-9 $\mathrm{m}$ and $21-29 \mathrm{~m}$, respectively. The use of this simple lithologic code 1 is intrinsically limited. The stacking pattern of the basic sequences readily suggests some kind of cyclic modulation as there appears to be recurring variations of their thickness (Figs. 2B, C, 3A). Code 2 time series better accounts for such observations and should be more suited to infer modulations acting on the basic sequences. Indeed, spectral analysis of code 2 series
(Fig. 2C) displays significant peaks both at the 8-12 $\mathrm{m}$ band and around $24 \mathrm{~m}$. These are compatible with the inferred bands on the code 1 time series. Consequently, a short-eccentricity origin ( $\sim 100 \mathrm{kyr}$ duration) may be attributed to the basic sequences while the band with periods of 8-12 m would represent the 400 kyr long eccentricity cycle. Moreover, in this context, the cyclicity with periods around $24 \mathrm{~m}$ might fit with the very long 1.2 Myr obliquity modulation cycle, which have already been detected in the Permian (Fang et al., 2015; Li et al., 2016). The alternative interpretation of the basic cycle as precession cycles $(\sim 21$ kyr) appears less likely as the $24 \mathrm{~m}$ period would be difficult to fit to any orbital period despite the 8-12 m could still fit to short eccentricity. Collectively, we favour the interpretation of the basic sequences as short eccentricity cycles driven by depositions in a monsoonal climate system. We conclude that the upper URU and lowermost Buntsandstein represent about 5.8 Myr of monsoonal deposition.

\subsection{Mineralogy and elemental succession}

Coll de Terrers section bulk rock mineralogy as studied by XRD allowed us to identify the following main minerals (in parentheses, SQPA values obtained with the RIR method are given): quartz (3-39.9\%), calcite (18.3-49.1\%), albite (0.8-18.5\%), clinochlore (4.5-33.9\%), hematite (0-5.3\%), kaolinite (1.3-18.9\%) and muscovite/ illite (5.4-45.3\%). Analcime (0-1.4\%) was only detected in two clusters found at the uppermost URU (between $135.5 \mathrm{~m}$ and $141.6 \mathrm{~m}$ of the measured section) (Fig. 4). Other minor phases (each one of $<1 \%$ in abundance) were found on specific levels, including microcline (between $14.5 \mathrm{~m}$ and $49.44 \mathrm{~m}$ ) and rutile (between $135.5 \mathrm{~m}$ and $148.1 \mathrm{~m}$ ). Fig. 4 shows the main mineral variations from the lower to the upper URU (18 samples from $4.4 \mathrm{~m}$ to $58.0 \mathrm{~m}$ of the measured section) and from the upper URU to the Buntsandstein facies (56 samples from $134.5 \mathrm{~m}$ to $148.1 \mathrm{~m}$ of the measured section).

The lower and upper URU display distinctive proportions of some minerals like quartz and kaolinite, which are abundant in the lower URU and depleted in the upper URU (Fig. 4). On the contrary, significantly larger amounts of albite and muscovite/illite are found in the upper URU relative to the lower URU. The simultaneous reduction of kaolinite and increase of albite may indicate a shift from humid to semiarid conditions (Schneider et al., 2006), which is in accordance with the sedimentary structures from the lower and upper URU, respectively (Figs. 2, 3, S1, S2). A similar palaeoclimatic trend of the Pyrenean units was proposed by Gascón and Gisbert (1987), who documented an aridification increase in the Permian. De la Horra et al. (2012) also reported a humid to semiarid climate transition in the middle-late Permian of the Iberian Basin, and Gómez-Gras and AlonsoZarza (2003), Linol et al. (2009) and Liebrecht et al. (2017) documented semiarid conditions for the uppermost Permian deposits of the Balearic Islands. The increase of muscovite/illite from the lower to the upper URU also suggests a change towards a semiarid climate, as has been documented in South China (Xu et al., 2017). The sizable decrease of quartz contents in the upper URU is possibly related to reduced chemical weathering (see also Williams et al., 2012), as this mineral is more resistant than feldspars and rock fragments (Coney et al., 2007). In turn, analcime occurs both as a primary mineral in alkaline igneous rocks but can also be authigenically formed (Remy and Ferrell, 1989; Schneider et al., 2006). The latter is the most possible origin of this mineral in Coll de Terrers, as no signals of igneous rocks have been found in the succession.

From the uppermost URU (142.6 m of the measured section) to the lowermost Buntsandstein red mudstones, significant increase of clinochlore contents accompanied with reduced hematite contents (as well as a slight decrease of albite) have been observed. Abundance of quartz and muscovite/illite remain nearly constant between the upper URU and the Buntsandstein facies. Peaks of albite and quartz are found in the basal Buntsandstein microbreccia, most probably corresponding to pebbles (Fig. 3G-I). In the grey interval of the basal Buntsandstein red 


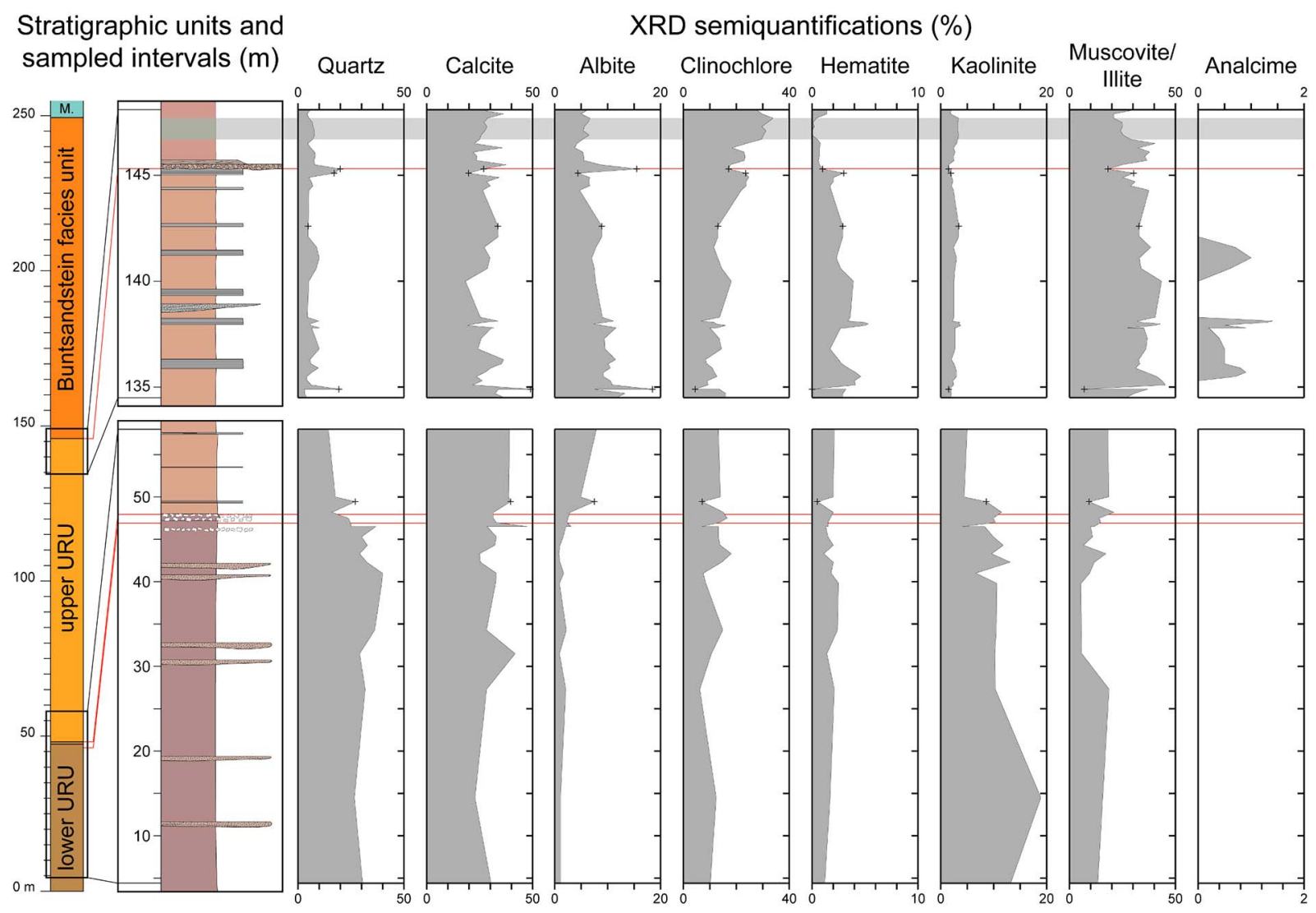

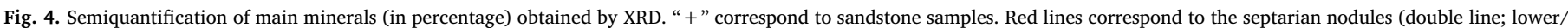

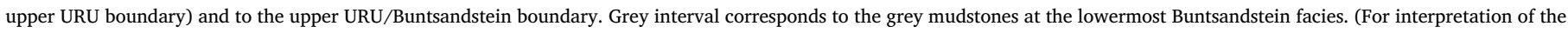
references to colour in this figure legend, the reader is referred to the web version of this article.)

mudstones (146.7-147.7 m of the measured section; Fig. 3H) albite and kaolinite slightly increase, clinochlore highly increases, muscovite/illite decreases and hematite is depleted. Recently, Xu et al. (2017) documented the appearance of chlorite (i.e., from the clinochlore group) across the Permian-Triassic transition in South China, being indicative of an accelerated aridification. The clinochlore increase across the upper URU/Buntsandstein transition may also indicate an intensified aridification. Thus, we conclude that most probably semiarid conditions persisted (and increased) across the upper URU and lowermost Buntsandstein, also supporting continuity in sedimentation throughout these units.

Trends of calcite are not considered here, as this mineral infills postdepositional fractures crosscutting the succession (Fig. 3C-E). Thus, part of the measured calcite is not from the rock composition but of diagenetic origin instead.

The mineralogical data was complemented with XRF measurements, which allowed us to monitor XRF signals for a range of major and trace elements (Al, Si, K, Fe, Cu, Rb and $\mathrm{Sr}$ in Fig. 5; Ca, Ti, Cr, Ni and $\mathrm{Pb}$ in Fig. S3). The most notable intensity trends (Fig. 5) reveal several changes across the three units:

1) Increase of $\mathrm{K}$ (and also of $\mathrm{Rb}$, which displays an equivalent trend) from the lower to the upper URU, consistent with the muscovite/illite increase.

2) Significant decrease of Fe accompanied by increased intensity of the $\mathrm{Cu}$ peak, across the upper URU/Buntsandstein boundary, coincident with the hematite reduction. Copper is generally related to environments with low oxygen levels (Hofmann et al., 2000; Hiete et al., 2006; Scholze et al., 2017), which could be linked to the decrease of hematite observed by XRD. This mineral is formed in oxic conditions, and therefore the observed hematite reduction may be a consequence of lower atmospheric oxygen levels (Hiete et al., 2006; Benton and
Newell, 2014).

3) Slight decrease of $\mathrm{Al}, \mathrm{K}$ and Fe signals in the Buntsandstein grey mudstone interval, relative to neighbouring materials, and increase of $\mathrm{Cu}$ and $\mathrm{Sr}$ (and possibly a minor increase of Ni, shown in Fig. S3) signals. These observations are coincident with the clinochlore increase, muscovite/illite reduction and hematite depletion, which could be related to anoxia in the lacustrine/playa-lake water (Hiete et al., 2006; see Section 5 below).

\subsection{Palaeontological content}

The Coll de Terrers fossil assemblage is mainly composed of tetrapod footprints and invertebrate trace fossils located at the upper URU. In the lower URU and Buntsandstein facies only invertebrate burrows and root trace fossils were identified. Thus the main focus of the section is on the Permian upper URU fossil record.

\subsubsection{Vertebrate footprints}

Prior to this study, the known URU vertebrate fossil record was limited to the unrecovered large tetrapod footprints from Palanca de Noves (stratigraphically located $116 \mathrm{~m}$ below the Triassic angular unconformity; Robles and Llompart, 1987), and to a synapsid caseid vertebra from La Trava (stratigraphically located $35 \mathrm{~m}$ below the Triassic angular unconformity; Mujal et al., 2016a). Coll de Terrers yields four tetrapod footprint morphotypes (I-IV), as well as several unclassifiable rounded and oval-shaped deep tracks characterised by large expulsion rims. Footprints are preserved in concave epirelief in the fine-grained sandstone layers of the upper URU. Such layers were cohesive substrates that enhanced footprinting. Herein we also reanalyse the footprints reported by Robles and Llompart (1987) to study the complete succession of tetrapod footprints along the Pyrenean URU. 


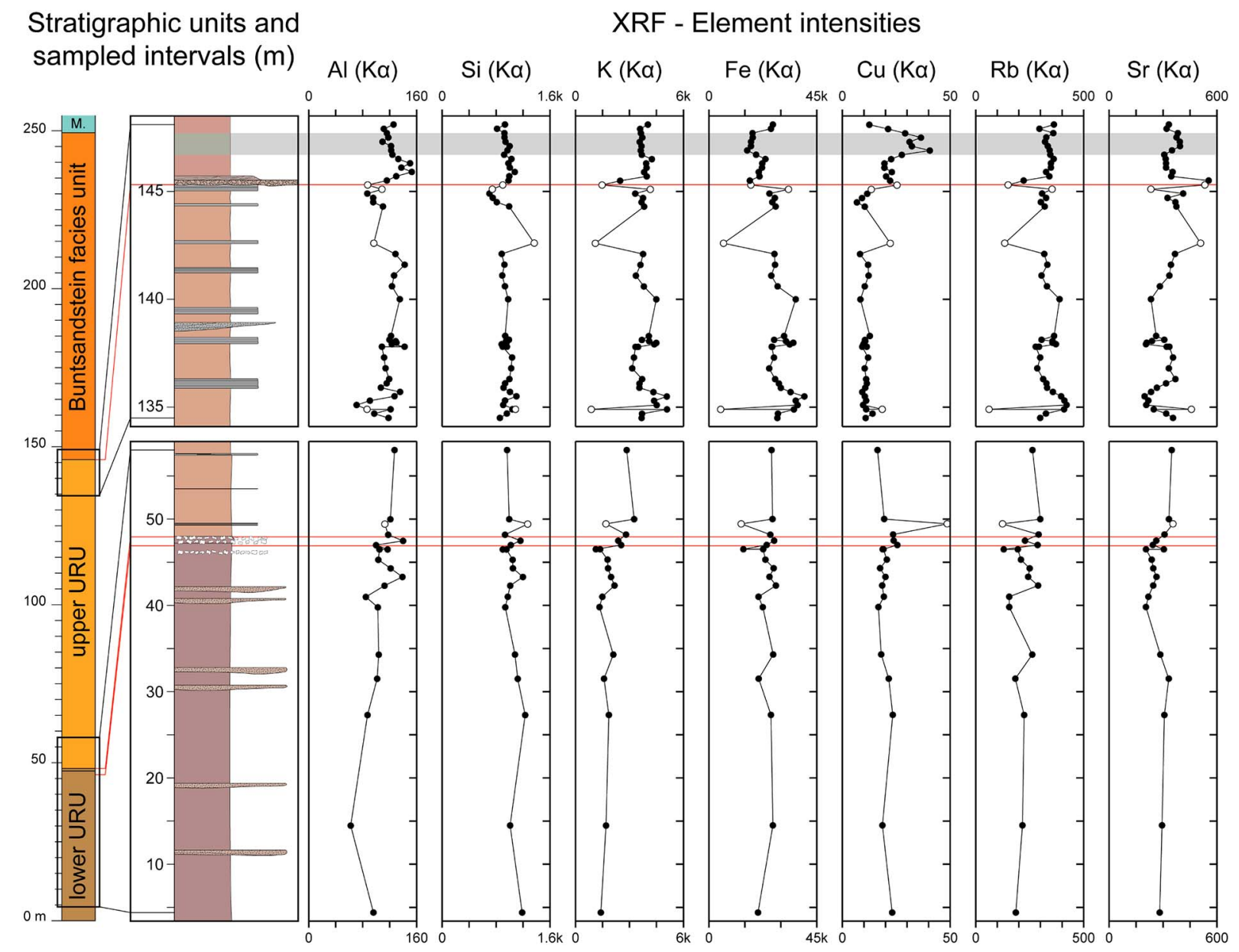

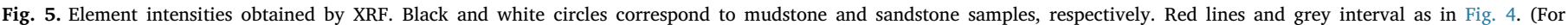
interpretation of the references to colour in this figure legend, the reader is referred to the web version of this article.)

These ichnites are currently lost due to construction of the road to the town of La Seu d'Urgell during the nineties, so our reanalysis is based on the descriptions and photographs published by these authors.

Morphotype I (Figs. 6A, B, S4, S5).

Description: This morphotype is found in the basal fine-grained sandstone layer of the sequences 9 (at $70.20 \mathrm{~m}$; Fig. S4A), 23 (at $95.20 \mathrm{~m}$; Figs. 6A, S4B-I) and 38 (at $119.80 \mathrm{~m}$; Figs. 6B, S5) of the measured section. Tracks of this morphology are settled in alternating manus-pes sets. Manus impressions are pentadactyl, semiplantigrade to plantigrade and wider than long. Manus digits, displayed in arch form, are short, mostly preserved as rounded tip impressions, with thin and shallow phalangeal pad marks (Fig. S5C). A low expulsion rim appears in the posterior (proximal) part of the tips of some tracks (Fig. S4B, C). Digit III is the longest, followed by digits IV, II and I. Digit V, the shortest, is just a faint impression. Digits I and II are the deepest, followed by digit III, digit IV is much less impressed. The palm is much wider than long, with a concave and shallow posterior margin. A rounded and deep impression is observed below digit I. The deepest part of the palm is an oval-shaped impression below digit III. Pes tracks are generally poorly preserved, they are longer than wide, pentadactyl and plantigrade, and in some cases partially overprint manus (Fig. 6A, S4C-I). When preserved, pedal digits are also displayed in arch form (Figs. 6B, S4A, S5). Digits are short and stubby, preserving oval- to round-shaped tips, slightly wider than long. In one track digits are elongated (Fig. S4G). Digit III is the longest, and digit V is the smallest. The posterior and outer half of the sole is the deepest impressed part of the footprint, in some cases surrounded by an expulsion rim (Fig. S4A). Trackway pace angulation is estimated to be around $90^{\circ}$ in both manus and pes tracks. Manus tracks are slightly rotated inwards, whereas pes tracks are slightly rotated outwards.

Remarks: The quadrupedal tracks, displayed in alternating manuspes sets, with low pace angulations and the shape of both manus and pes impressions are characters found in the Dicynodontipus tracks of the late Permian Cistecephalus Assemblage Zone from the South African Karoo Basin (de Klerk, 2002). This ichnogenus is also recorded in the late Permian from Italy (Kustatscher et al., 2017), and the Early and Middle Triassic from Australia (Retallack, 1996), Germany and Britain (Haubold, 1971). The different track preservations are related to substrate rheology (i.e., moisture and water content). Such variety of preservations, as well as the partial overprinting of pes to manus impressions, and the footprint depth patterns, were also observed by de Klerk (2002) in the late Permian of South Africa. All these features suggest that the Coll de Terrers tracks are most probably close related to the South African Dicynodontipus footprints if not the same. The lack of more detailed tracks and complete trackways preclude ichnogeneric assignation. Overall, the Coll de Terrers tracks could represent the first record of Dicynodontipus in the Permian of Western Europe. If true, this record suggests a late Permian age for the upper URU of Coll de Terrers.

Morphotype II (Figs. 6C, S6).

Description: Footprints of this morphology are found in different fine-grained sandstone layers of the sequence 39 , at $120 \mathrm{~m}$ of the measured section (Figs. 6C, S6). Tracks are arranged in manus pes sets. Tracks are nearly rounded and slightly wider than long. Manus (about $10 \mathrm{~cm}$ wide, $7 \mathrm{~cm}$ long) are smaller and more oval-shaped than pes tracks (about $15 \mathrm{~cm}$ wide and long). Manus are semiplantigrade, with only three short and rounded digits preserved (I, II and III, in increasing 

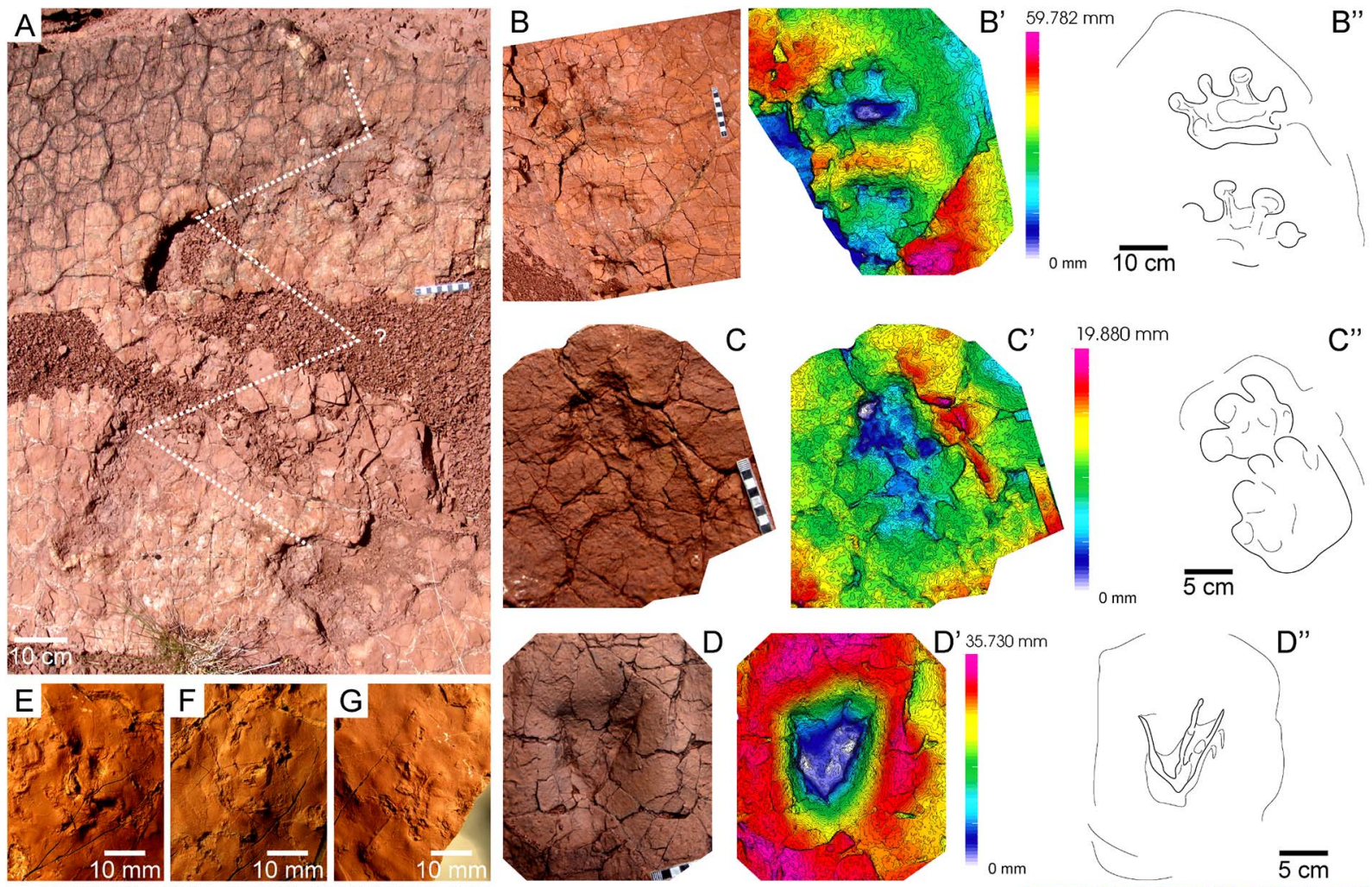

.

$5 \mathrm{~cm}$
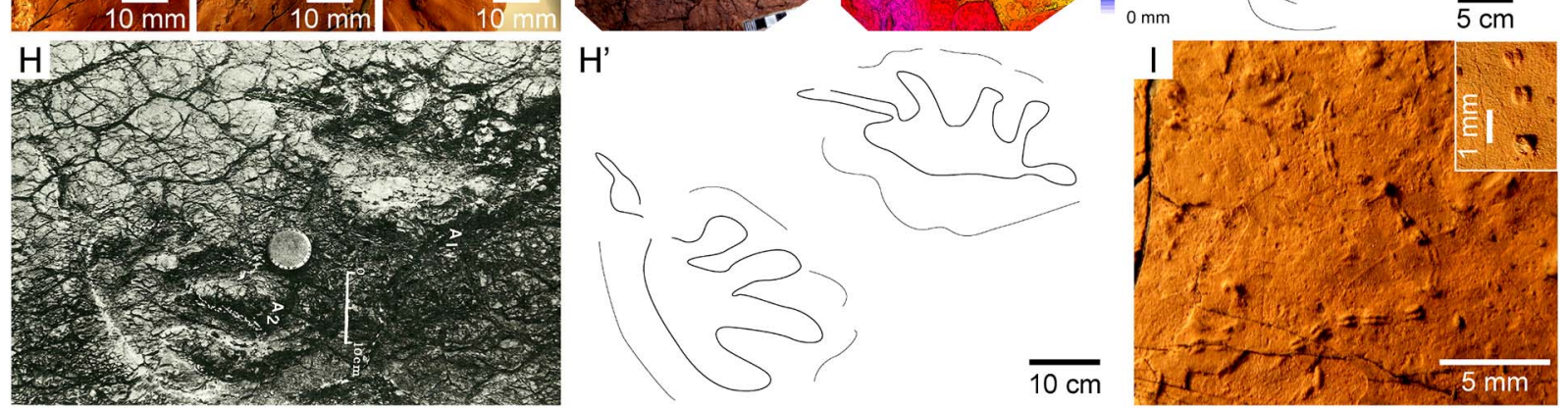

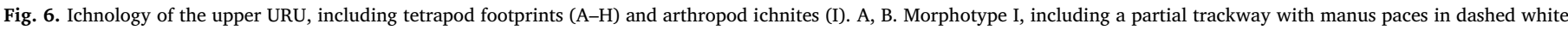

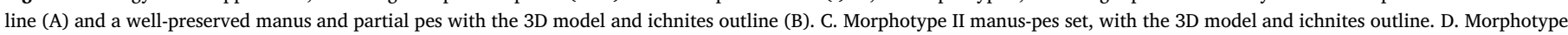

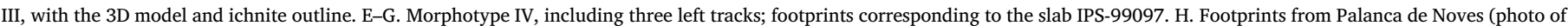
"forms A" modified from Robles and Llompart, 1987) and ichnites outline. I. Ichnites preliminary attributed to Acripes and Rusophycus.

length). Digit II is the most deeply impressed, followed by digit I. Digit III is slightly shallower than palm impression, which is deeper below digit I (Fig. 6C). Manus is slightly rotated inwards respect to pes impression. Pes tracks are nearly rounded, plantigrade to semiplantigrade, mostly preserving digits I to IV, in increasing length and depth. Digit I is much shorter than digit II; digits III and IV are nearly equal in length. A rounded and relatively deep impression is observed in the sole below digit I. The outer half of the sole is the deepest impressed part. A shallow ridge divides the sole between digit I and its basal pad from the rest of the footprint.

Remarks: The slightly wider than long footprints and their size, with pes larger than manus impressions and the stubby digits in increasing length from I to IV, are traits of Pachypes, a late Permian ichnogenus recorded from Italy (Valentini et al., 2009; Kustatscher et al., 2017), Morocco (Voigt et al., 2010), Niger (Smith et al., 2015) and possibly from Russia (Valentini et al., 2009; but see Gubin et al., 2003; Surkov et al., 2007; Voigt et al., 2010). Track preservations preclude a confident assignation, but all the previous characters suggest Pachypes (or a close related one) as the most favoured ichnotaxon for Morphotype II.

Morphotype III (Figs. 6D, S7).

Description: This morphotype is preserved in the basal layer of the sequence 27, at $100.98 \mathrm{~m}$ of the measured section (Figs. 6D, S7).
Footprints are deeply impressed, bordered by relatively high and wide expulsion rims. They preserve three thin and long digits, representing about $2 / 3$ of the total footprint length. Two of the three digits are nearly parallel, while the other digit is separated, with a higher angle of divarication. Digit tips are rounded. The heel, narrower than the total digits width, shows different shapes, appearing as a smoothed triangle, slightly curved (convex), or separated by a ridge from the rest of the impression (Fig. S7A-F, H, I). Some tracks are rather aligned and alternated, possibly corresponding to the same trackway, although patterns are not regular (Fig. S7G, J). If these tracks correspond to a trackway, the most separated digit would correspond to digit I, as it would be in the footprint inner (medial) part.

Remarks: The asymmetrical fork-like shape of these footprints, only preserving three digits, is unknown from any Permian tetrapod footprint morphotype. Therefore, this shape most probably results from a specialized gait in a soft (but cohesive) substrate. Anatomical features are hardly preserved, precluding a confident assignation. In addition, the original track surface may be covered or eroded, thus some tracks may correspond to overtracks or undertracks, respectively. This occurs in microbial mats from tidal flats, where water content variation and surface mud-cracking are frequent (Marty et al., 2009), hence being similar to the upper URU sandstone layer substrates. 
Morphotype IV (Figs. 6E-G, S8).

Description: These footprints were found in two ex situ blocks $7 \mathrm{~cm}$ thick (including IPS-99097, Fig. S8) at the uppermost URU, close to the sandstone channel (sequence 49) at $138.5 \mathrm{~m}$ of the measured section. Footprints are pentadactyl, digitigrade and longer than wide. Measuring about $2.5 \times 2 \mathrm{~cm}$, they are the smallest vertebrate ichnites of Coll de Terrers. Digits are thin and long, in increasing length from I to IV, which are curved inwards. Occasionally digit I is not preserved. Digit V, rotated and curved outwards, is between digits I and II in length. Digit tips are clawed. Despite the fact that surfaces are plenty of tracks, no manus-pes sets nor trackways are recognized.

Remarks: Small-sized footprints with this asymmetrical shape, due the relative length of the slender and curved digits, may be attributed to either Dromopus or Rhynchosauroides (e.g., Haubold, 1971). Dromopus is mostly recognized in Lower Permian deposits (Marchetti, 2016), whereas Rhynchosauroides is identified in the Upper Permian record (Valentini et al., 2007, 2009). Similar footprints from the late Permian of the Nigerian Moradi formation were attributed to Dromopus by Smith et al. (2015) although further detailed studies are necessary for a confident ichnotaxonomy. Therefore, and due to track preservation, we refer Morphotype IV to a Dromopus-Rhynchosauroides plexus awaiting further analysis.

Footprints published by Robles and Llompart (1987) (Fig. 6H).

Description: These authors described four ichnites preserved in concave epirelief and located in the URU, $116 \mathrm{~m}$ below the Triassic unconformity at the Palanca de Noves site. Footprints are pentadactyl and plantigrade to semiplantigrade, probably corresponding to the same trackway. Robles and Llompart (1987) differentiated four forms: $A_{1}, A_{2}, B_{1}$ and $B_{2}$. Ichnites $A_{1}$ and $A_{2}$ correspond to a manus and a pes, respectively, building up a right couple. $B_{1}$ and $B_{2}$ correspond to a pes and a manus, respectively, from two different (but consecutive) left sets. Manus is much wider (ca. $35 \mathrm{~cm}$ ) than long (ca. $19 \mathrm{~cm}$ ), and with relatively long digits (about $1 / 3$ of the total footprint length) with rounded tips. Digit I is elongated and rotated backwards. Digit III is the longest, followed by digit IV and digit II. Digit V is slightly shorter than digit I. The palm, wider than long, is oval shaped. Pes track is wider (ca. $33 \mathrm{~cm}$ ) than long (ca. $20 \mathrm{~cm}$ ). Digits III and IV are the longest, followed by digit II. Digits I and V, similar in length, and much shorter than the others. In the right manus-pes set, manus is rotated inwards and closer to the trackway midline than pes track, which is nearly parallel to the midline. If these footprints build up a single trackway, pace angulation is relatively low, about $90^{\circ}$.

Remarks: These tracks were correlated to different trackmakers by Robles and Llompart (1987): the forms A were identified as temnospondyl or seymouriamorph tracks, and the forms B as a reptile-like track or a chirotheriid. Nevertheless, these tracks most probably correspond to a single trackway, thus such morphological variations are related to locomotion and substrate rheology. Two ichnogenera present the characters described above: 1 ) the Dicynodontipus tracks from the Cistecephalus Assemblage Zone (late Permian) at the South African Karoo Basin (de Klerk, 2002), and 2) the Merifontichnus tracks from the La Lieude formation (middle Permian) at the French Lodève Basin (Gand et al., 2000; Gand and Durand, 2006) and possibly from the late early Permian of the Italian Orobic Basin (Marchetti, 2016). With the available data, ichnotaxonomy should remain open, although considering the age of the succession (see discussion in Section 5 below), Merifontichuns is the favoured ichnogenus for these ichnites.

\subsubsection{Invertebrate trace fossils and plant remains}

Invertebrate ichnites occur in the three Coll de Terrers units. In the distal meandering and floodplain systems of the lower URU, sandstone channels preserve either vertical or oblique, cylindrical and slightly sinuous bioturbations infilled by wine-reddish mudstone (Fig. S1E). Plant fragments and root traces are also preserved along the lower URU (Fig. S1F, S2B).

Several fine-grained sandstone layers of the upper URU yield both vertical and horizontal (and ramified) cylindrical bioturbations of up to $1 \mathrm{~cm}$ of diameter (Fig. S9A-E). When present, vertical burrows are relatively abundant (Fig. S9A). Gisbert (1981) attributed the vertical burrows to bivalves. Otherwise, ramified and horizontal burrows may correspond to arthropods. The lowermost surfaces of some fine-grained sandstone layers preserve abundant trace fossils with two differentiated morphologies: 1) Ichnites of $<1 \mathrm{~mm}$ to $3 \mathrm{~mm}$ long, oval-shaped and bilobated (i.e., "coffee grain-like" shape; Figs. 6I, S9G-J), attributed to Rusophycus, which is a common Permian-Triassic resting trace fossil (Gand et al., 2008); 2) relatively long and sinuous ichnites composed of two parallel ribbons with a medial ridge, often associated with Rusophycus (Figs. 6I, S9I, S9J); these impressions resulted from locomotion, probably corresponding to Acripes (or close related) ichnogenus (Gand et al., 2008). These ichnites were impressed in a submerged substrate, as their trackmakers, notostracan arthropods (triopsids), are unable to move out of water (Gand et al., 2008). Associated with some of these arthropod ichnites, several globular structures possibly corresponding to pellets are also recognized (Fig. S9J).

\subsection{Correlation with the Pyrenean record}

The Coll de Terrers succession is integrated with those from Palanca de Noves at the Segre river valley (3.87 km Westwards; Gisbert et al., 1985; Robles and Llompart, 1987) and La Trava-Coll de Creus $(6.85 \mathrm{~km}$ Eastwards; Gretter et al., 2015; Mujal et al., 2016a), which present significant differences (Figs. 1, 7). The major and traceable feature is the Westwards and Eastwards thickening of the Buntsandstein facies, which overlie the URU in angular unconformity and local conformity in the studied area (Fig. 7). Such thickening was the result of erosive depocentres located to the $\mathrm{W}$ and $\mathrm{E}$ of Coll de Terrers (e.g., the number of upper URU cycles at Coll de Creus is $<30$, whereas Coll de Terrers preserves 54 cycles; Fig. 1C). Coll de Terrers remained as a topographic high where accommodation was reduced (e.g., the Buntsandstein unit thickness at Coll de Terrers is of $103 \mathrm{~m}$ and in Palanca de Noves is of $213 \mathrm{~m}$ ). The cycles at the lowermost part of the Buntsandstein from Coll de Terrers have not been identified at any other area of the Catalan Pyrenees. Instead, in the other successions the basal conglomerates of alluvial braided systems are overlaid by fine- to medium-grained sandstones and mudstones of fluvial (mostly meandering) and floodplain systems (Mujal et al., 2016a, 2017). This feature denotes that in Coll de Terrers the basal Buntsandstein deposits record a singular environment of low energy (i.e., playa-lake or ephemeral lacustrine) instead of the coarse braided systems found in other Pyrenean regions (Gisbert et al., 1985; Gretter et al., 2015). In all, the basal thick braided successions preserved out of Coll de Terrers represent by-pass deposits of relatively long periods of sediment reworking. As a result, the Coll de Terrers Permian deposits were not exposed to any major erosion, and the Permian-Triassic succession is in continuity (i.e., strike and dip angles, and sedimentary setting do not change across the URU/Buntsandstein boundary, thus the usual Triassic angular unconformity is not present at all). This feature is exceptional in the Pyrenees and probably within the continental deposits of Western Europe (Bourquin et al., 2007, 2011; Gretter et al., 2015).

\section{Discussion}

The Permian-Triassic transition from the Catalan Pyrenees has been recently investigated by Mujal et al. (2016a). These authors documented a lack of record of about 15-19 Myr between the Permian and Triassic successions in sections preserving well-developed conglomerates at the base of the Buntsandstein from Palanca de Noves and La Trava sections. In this last section, a synapsid caseid vertebra from the uppermost part of the lower URU was tentatively correlated to the Wordian (middle Permian), thus suggesting that the upper URU is younger. The correlation of the Pyrenean lower and upper URU fossil localities shows that the Palanca de Noves tracks reported by Robles 
(Gisbert et al., 1985; Robles and Llompart, 1987; Mujal et al., 2016a)

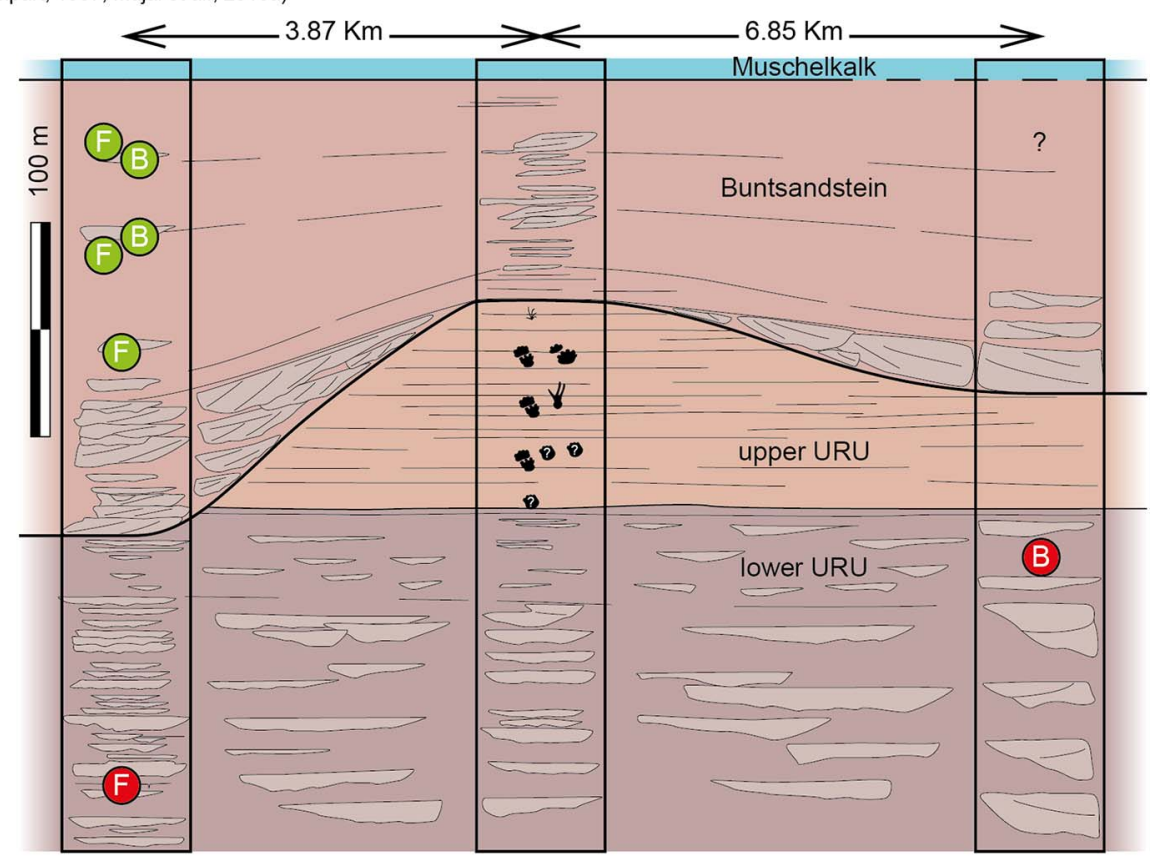

Fig. 7. Correlation of the URU-Buntsandstein sequences with the stratigraphic position of the URU vertebrate remains. Previously published tetrapod bones (B) and footprints $(F)$ are indicated in red for the URU and in green for the Buntsandstein facies. Symbols of Coll de Terrers tetrapod footprints as in Fig. 2. (For interpretation of the references to colour in this figure legend, the reader is referred to the web version of this article.) and Llompart (1987) were stratigraphically below the caseid vertebra (Fig. 7). These ichnites were preserved in thin mudstone and thinbedded sandstone intervals settled in a succession with abundant levels of conglomeratic alluvial channels (Robles and Llompart, 1987), thus corresponding to the lower URU. In our analyses we found that these ichnites could be attributed to either Merifontichnus or Dicynodontipus. Considering the inferred age for the caseid vertebra (early middle Permian), the Palanca de Noves tracks, which are older than the vertebra, more likely correspond to Merifontichnus. This ichnogenus is known from the middle Permian La Lieude formation of France (Gand et al., 2000; Gand and Durand, 2006), whereas Dicynodontipus is known from the late Permian Cistecephalus Assemblage Zone of South Africa (de Klerk, 2002) and the late Permian of the Northern Italian Bletterbach Gorge, Dolomites (Kustatscher et al., 2017 and references therein).

These biostratigraphic inferences can be compared and coupled with the sedimentological and mineralogical trends of the succession. The lower to upper URU deposits record a transition from humid to semiarid conditions (Fig. 8). This climatic shift is possibly related to that of the upper portion of the Alcotas formation in the Iberian Basin (De la Horra et al., 2012) and also to the climatic shift documented in the early late Permian of northern Pangaea (Retallack et al., 2006; Roscher and Schneider, 2006; Słowakiewicz et al., 2009). This may imply that the lower/upper URU boundary could be correlated with the middle-late Capitanian (around the middle Permian extinction event) (Retallack et al., 2006; Sheldon et al., 2014; Day et al., 2015). Nevertheless, the lower/upper URU boundary possibly represents a paraconformity or sedimentary hiatus (i.e., long periods of exposition and development of levels with large nodules; Fig. 8, S2); no evidences of the middle Permian extinction have been identified in the Pyrenees so far.

The upper URU records a cyclic alternation of facies, from mudstones to fine-grained sandstones, related to a monsoon system of orbital recurrence (Figs. 2, 3A, B). Such duality of facies would represent the seasonality proposed in the late Permian palaeoclimatic model of Roscher et al. (2011). Similarly, late Permian seasonality has also been documented in the Central Pangaean Moradi formation of Niger (Looy et al., 2016) and the Southern Pangaean Karoo Basin of South Africa (Gastaldo et al., 2015). The tetrapod footprint morphotypes I and II recovered in Coll de Terrers were potentially produced by similar (or the same) trackmakers as those corresponding to Dicynodontipus and Pachypes (i.e., dicynodonts and pareiasaurs, respectively), being present at the Karoo Basin (de Klerk, 2002) and at the Moradi formation (Smith et al., 2015), respectively. In fact, the upper URU mudstones are barren of fossils, but the thin-bedded sandstone layers preserve tetrapod footprints, possibly indicative of periods of more favourable conditions for life development. The presence of burrows and notostracan ichnites may indicate that the fine-grained sandstone layers acted as a source of food. These ichnites were impressed in a submerged substrate, as their trackmakers are unable to move out of water (Gand et al., 2008), further denoting different conditions than those of the muddy intervals. Noteworthy, the thin-bedded sandstone layers record periods of subaerial exposure (Figs. 3B-E, 6A, 8) that, together with the notostractan ichnites, indicate recurrent dry and wet periods. This is indicative of a similar seasonality to that of Central Pangaea (Looy et al., 2016).

The correlation of the monsoonal sequences with $400 \mathrm{kyr}$ eccentricity cycles implies that the upper URU and the lowermost Buntsandstein were deposited along $\sim 5.8 \mathrm{Myr}$. In this way, the aridification observed at the upper URU would be at least of 5.3-5.4 Myr older than the upper URU/Buntsandstein boundary. The lack of any major erosion and the URU/Buntsandstein concordant contact both suggest that the Permian-Triassic boundary (PTB) could be preserved somewhere in the uppermost URU or lowermost Buntsandstein, possibly in the URU/Buntsandstein boundary itself (Fig. 8). Note also that the URU/Buntsandstein boundary does not show a disruption in the cyclicity (Fig. 2C). This agrees with the suggested correlation of the upper URU with the early late Permian aridification and with the South African Cistecephalus Assemblage Zone. The presence of tractive structures in the uppermost URU at Coll de Terrers (e.g., channel at $138.5 \mathrm{~m}$ of the measured section; Fig. $3 F$ ) denote a higher water flow (i.e., increase in water flow) than that of the thin-bedded sandstone layers. This switch to more energetic conditions at the uppermost URU culminated with the basal Buntsandstein microbreccia (Figs. 3G-I, 8). A similar energetic increase of the sedimentary style has been documented in the Permian-Triassic transition of the Iberian Basin (Arche and López-Gómez, 2005), Russia (Newell et al., 2010; Benton and Newell, 2014), central India (Chakraborty and Sarkar, 2005), South 


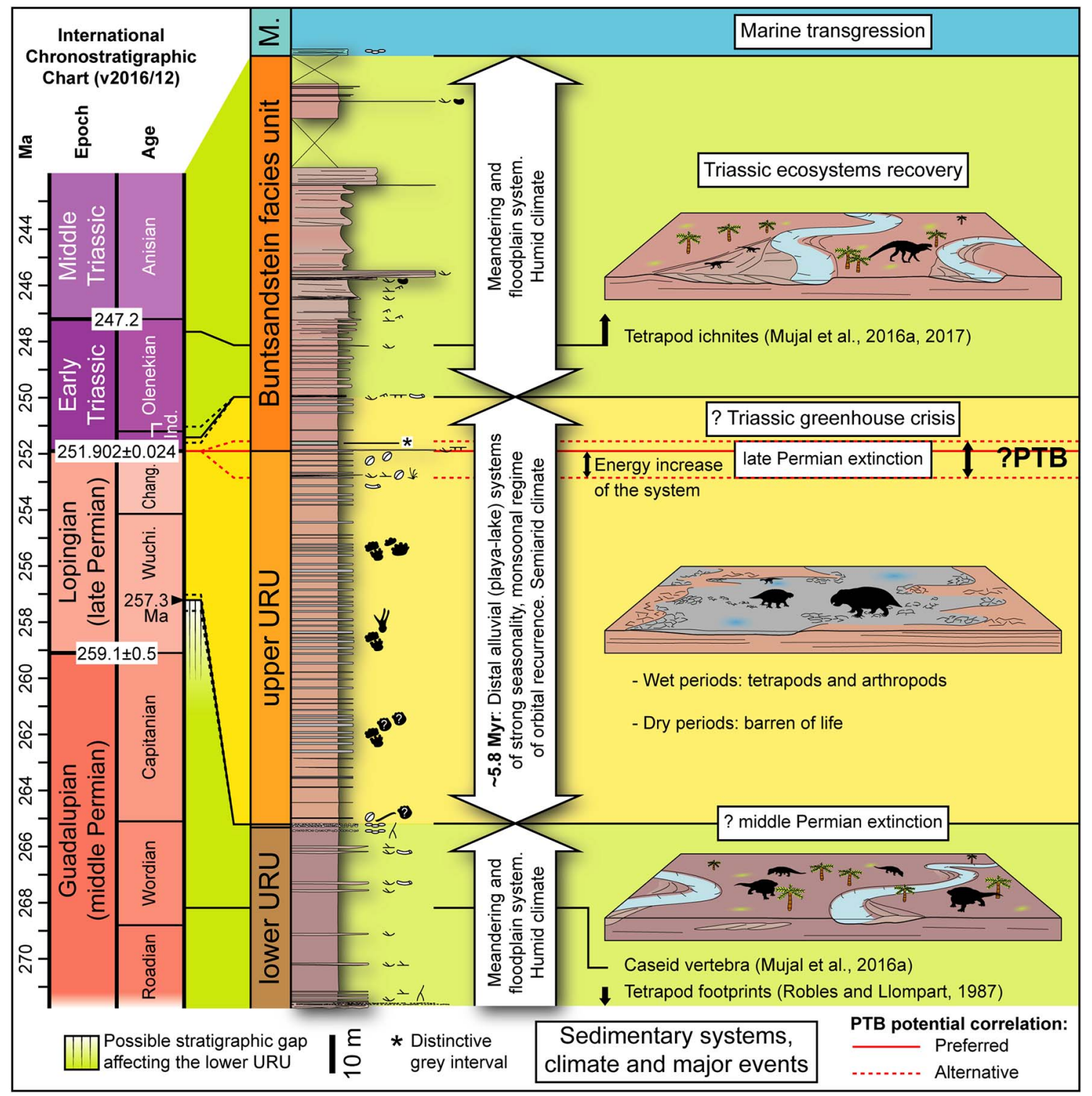

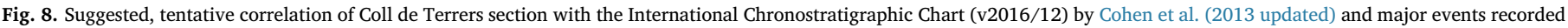
at the studied area. Ind.: Induan. Chang.: Changhsingian. Wuchi.: Whuciapingian. M.: Muschelkalk facies.

China (Zhang et al., 2016), South Africa (Ward et al., 2000), the Antarctica (Retallack et al., 2005) and Australia (Michaelsen, 2002). This energetic increase is related to the loss of plants that fix the substrate on account of the end-Permian extinction (Retallack et al., 1998, 2006; Michaelsen, 2002; Benton and Newell, 2014). In addition, the clinochlore increase throughout the URU/Buntsandstein transition can be correlated with the intensified aridification across the PTB in South China, where similar mineralogical trends have been detected (Xu et al., 2017).

Another particular sedimentological feature of Coll de Terrers is the sudden switch from red to grey mudstones in the lowermost Buntsandstein (Fig. 3J). Accordingly, this 1-m-thick grey mudstone interval shows a sudden shift of several minerals and elements (Figs. 4, 5, S3). Particularly, the hematite depletion and the increase of $\mathrm{Cu}$ and $\mathrm{Sr}$ (and also the minor increase that seems to occur in the case of $\mathrm{Ni}$ ) possibly denote anoxic conditions. Grey intervals with $\mathrm{Cu}$ enrichments, related to anoxia, are recorded in the lowermost Buntsandstein of the Central European Basin, Central Germany (Hiete et al., 2006; Scholze et al., 2017). Noteworthy, the end-Permian extinction is correlated with oceanic anoxia and acidification (Grice et al., 2005; Meyer and Kump, 2008) that influenced atmosphere (Kump et al., 2005). In this way, in marine sections of South China, spikes of $\mathrm{Cu}$ and $\mathrm{Ni}$ related to the Siberian volcanism coincide with the end-Permian extinction event (Rothman et al., 2014). Strontium increase across the PTB has been related to increased acidic conditions in the Iberian Basin (BorruelAbadía et al., 2016). Similarly, acidification across the PTB has also been suggested in successions from South China, being possibly related to a global event (Xu et al., 2017). With the present elemental data, such interpretations for Coll de Terrers still remain open, although peaks of $\mathrm{Sr}$ and $\mathrm{Al}$ are also observed at the lowermost Buntsandstein mudstones (Fig. 5). Coney et al. (2007) suggested that no distinct geochemical signatures are found across the PTB in the South African Karoo Basin, although that could be due to the lithological differences of the analysed sections. On the contrary, Williams et al. (2012) found geochemical trends correlated with the global record in the Australian Sidney Basin. Further geochemical analysis at Coll de Terrers will shed light on this terrestrial record and its potential correlation with marine sections.

Regarding the age of the Buntsandstein facies, Mujal et al. (2016a) established a late Olenekian (late Early Triassic) age for the portion of the unit overlying the basal conglomerates at Palanca de Noves, where no monsoonal sequences as those of Coll de Terrers are observed. As 
already mentioned (see Section 4.5 above), the well-developed conglomeratic deposits from Palanca de Noves would correspond to bypass deposits, and thus may not preserve the lowermost Triassic record, as also occurs in La Trava (Fig. 7). Therefore, the basal conglomerates at Palanca de Noves are directly overlaid by meandering deposits (Mujal et al., 2016a). The 4-5 monsoonal sequences from the Coll de Terrers Buntsandstein correspond to the earliest Triassic record. Both sedimentological and mineralogical data indicate that these deposits formed under (increased) semiarid conditions, and thus they are probably related to the Early Triassic greenhouse crises (Retallack et al., 2011; Retallack, 2013). The overlying meandering deposits correlate with those of Palanca de Noves and La Trava (Fig. 7) and indicate a shift towards more humid conditions. At Palanca de Noves, such deposits yield a relatively diverse tetrapod ichnofauna and scarce bone remains (Fig. 7) related to the Early-Middle Triassic vertebrate recovery (Mujal et al., 2016a; see also Mujal et al., 2017 for further Buntsandstein Pyrenean ichnite localities). All these features are possibly indicative of the transition to cooler temperatures at the end of the Early Triassic (Rey et al., 2016).

Further prospections, analyses and major efforts, including more detailed XRD and XRF studies and isotopic analyses as well, are required to elucidate the age of the Permian-Triassic deposits of Coll de Terrers and other Pyrenean areas, and the potential biological crises recorded therein.

\section{Conclusions}

The Catalan Pyrenees, together with other regions from the Western peri-Tethyan domain, are a key target to decipher the late Palaeozoic-early Mesozoic events. Here we have provided new data on the continental Permian-Triassic transition of a recently identified area, Coll de Terrers. The sedimentary succession of the uppermost Permian units records different environments that, supported by the XRD analyses, point towards a transition from humid to semiarid climate that correlates with the late Permian aridification. The tetrapod ichnoassemblage also suggests a late Permian age for the uppermost Permian.

The late Permian succession was deposited under a monsoonal regime (already documented in equatorial Pangaea) in a low-energy setting (i.e., a distal alluvial plain), and orbital forcing imprint recurrence conditions (i.e., potential eccentricity and long-term obliquity cycles, hitherto unknown in the Permian-Triassic record of the Iberian Peninsula). The continuous sedimentary succession and the lack of any major erosion across the uppermost Permian and lowermost Triassic deposits imply the potential record of the Permian-Triassic boundary. This is supported by a sudden increase of the system energy and an intensified aridification close to the Permian-Triassic transition (documented in both northern and southern Pangaea), the possible anoxic interval in the lowermost Triassic deposits, and also by the lack of any major erosion and sedimentary hiatus as indicated by the preliminary cyclostratigraphic results.

In summary, Coll de Terrers records events and features globally recognized in Permian-Triassic terrestrial successions. This area, located in a narrow rift system at the Gondwana and Laurasia confluence, emerges as a reference zone to investigate the Permian-Triassic transition in terrestrial settings often characterised by scarcity of stratigraphic record. Further ongoing works will clarify whether the Permian-Triassic boundary is recorded in this Pyrenean terrestrial succession and in equivalent areas as well. This is the first contribution to improve correlations between northern and southern Pangaean regions, shedding new light on the terrestrial Permian extinction events.

Supplementary data to this article can be found online at https:// doi.org/10.1016/j.gloplacha.2017.10.004.

\section{Acknowledgments}

We acknowledge fieldwork support by Josep Marmi and Mireia Plà, preparation of thin rock samples by Luis Gordón and Marc Puigcerver at $\mathrm{UAB}$, and XRD and XRF data acquisition and analysis by Josep Elvira and Soledad Álvarez at ICTJA-CSIC. E. Mujal acknowledges N.-E. Jalil (MNHN), S. Jiquel, B. Marandat, L. Marivaux, M. Vianey-Liaud, P.-O. Antoine and all ISE-M staff their kind help in the collection visits. We acknowledge comments and suggestions from three anonymous reviewers that have improved a previous version of the manuscript, as well as the editor Prof. Sierd Cloetingh for handling the manuscript. E. Mujal obtained financial support from the PIF grant of the Geology Department at UAB, and from the Erasmus + program of the UAB performed at the Palaeontology Department from the Institut des Sciencies de l'Evolution (Université de Montpellier, France). E. Mujal received funding from the SYNTHESYS Project http://www.synthesys. info/ (FR-TAF-3621, FR-TAF-4808) which is financed by European Community Research Infrastructure Action under the FP7 "Capacities" Program. J. Fortuny acknowledges the support of the postdoc grant "Beatriu de Pinós" 2014 - BP-A 00048 from the Generalitat de Catalunya as well as from the Spanish Ministerio de Economía, Industria y Competitividad and the European Regional Development Fund of the European Union (MINECO/FEDER EU, project CGL201454373-P). J. Pérez-Cano acknowledges the support from the Spanish Ministerio de Economía, Industria y Competitividad (FPI grants BES2016-076469). This work received support from CERCA programme at Institut Català de Paleontologia (ICP) and from the projects "Vertebrats del Permià i el Triàsic de Catalunya i el seu context geològic" and "Evolució dels ecosistemes amb faunes de vertebrats del Permià i el Triàsic de Catalunya" (ref. 2014/100606), based at ICP and financially supported by the Departament de Cultura (Generalitat de Catalunya).

\section{References}

Alroy, J., 2013. Online paleogeographic map generator. http://paleodb.org/?a= mapForm.

Arche, A., López-Gómez, J., 2005. Sudden changes in fluvial style across the PermianTriassic boundary in the eastern Iberian Ranges, Spain: analysis of possible causes. Palaeogeogr. Palaeoclimatol. Palaeoecol. 229, 104-126. http://dx.doi.org/10.1016/ j.palaeo.2005.06.033.

Benton, M.J., Newell, A.J., 2014. Impacts of global warming on Permo-Triassic terrestrial ecosystems. Gondwana Res. 25 (4), 1308-1337. http://dx.doi.org/10.1016/j.gr. 2012.12.010.

Borruel-Abadía, V., López-Gómez, J., De la Horra, R., Galán-Abellán, B., Barrenechea, J.F., Arche, A., Ronchi, A., Gretter, N., Marzo, M., 2015. Climate changes during the early-middle Triassic transition in the E. Iberian plate and their palaeogeographic significance in the western Tethys continental domain. Palaeogeogr. Palaeoclimatol. Palaeoecol. 440, 671-689. http://dx.doi.org/10.1016/j.palaeo.2015.09.043.

Borruel-Abadía, V., Barrenechea, J.F., Galán-Abellán, A.B., Alonzo-Azcárate, J., De la Horra, R., Luque, F.J., López-Gómez, J., 2016. Quantifying aluminium phosphatesulphate minerals as markers of acidic conditions during the Permian-Triassic transition in the Iberian Ranges, E Spain. Chem. Geol. 429, 10-20. http://dx.doi.org/10. 1016/j.chemgeo.2016.03.007.

Bourquin, S., Durand, M., Diez, J.B., Broutin, J., Fluteau, F., 2007. The Permian-Triassic boundary and lower Triassic sedimentation in western European basins: an overview. J. Iber. Geol. 33 (2), 221-236.

Bourquin, S., Bercovici, A., López-Gómez, J., Diez, J.B., Broutin, J., Ronchi, A., Durand, M., Arche, A., Linol, B., Amour, F., 2011. The Permian-Triassic transition and the onset of Mesozoic sedimentation at the northwestern peri-Tethyan domain scale: palaeogeographic maps and geodynamic implications. Palaeogeogr. Palaeoclimatol. Palaeoecol. 299 (1-2), 265-280. http://dx.doi.org/10.1016/j.palaeo.2010.11.007.

Chakraborty, T., Sarkar, S., 2005. Evidence of lacustrine sedimentation in the Upper Permian Bijori Formation, Satpura Gondwana basin: Palaeogeographic and tectonic implications. J. Earth Sys. Sci. 114 (3), 303-323. http://dx.doi.org/10.1007/ BF02702952.

Chumakov, N.M., Zharkov, M.A., 2003. Climate during the Permian-Triassic biosphere reorganizations. Article 2. Climate of the Late Permian and Early Triassic: general inferences. Stratigr. Geol. Correl. 11 (4), 55-70.

Chu, D., Yu, J., Tong, J., Benton, M.J., Song, H., Huang, Y., Song, T., Tian, L., 2016. Biostratigraphic correlation and mass extinction during the Permian-Triassic transition in terrestrial-marine siliciclastic settings of South China. Glob. Planet. Chang. 146, 67-88. http://dx.doi.org/10.1016/j.gloplacha.2016.09.009.

Cohen, K.M., Finney, S.C., Gibbard, P.L., Fan, J.-X., 2013. The ICS international chronostratigraphic chart. Episodes 36, 199-204 (updated).

Coney, L., Reimold, W.U., Hancox, P.J., Mader, D., Koeberl, C., McDonald, I., Struck, U., Vajda, V., Kamo, S.L., 2007. Geochemical and mineralogical investigation of the Permian-Triassic boundary in the continental realm of the southern Karoo Basin, South Africa. Palaeoworld 16, 67-104. http://dx.doi.org/10.1016/j.palwor.2007.05. 003. 
Day, M.O., Ramezani, J., Bowring, S.A., Sadler, P.M., Erwin, D.H., Abdala, F., Rubidge B.S., 2015. When and how did the terrestrial mid-Permian mass extinction occur? Evidence from the tetrapod record of the Karoo Basin, South Africa. Proc. R. Soc. B 282, 20150834. http://dx.doi.org/10.1098/rspb.2015.0834.

de Klerk, W.J., 2002. A dicynodont trackway from the Cistecephalus assemblage zone in the Karoo, east of Graaff-Reinet, South Africa. Palaeontol. Afr. 91 (38), 73-91.

De la Horra, R., Galán-Abellán, A.B., López-Gómez, J., Sheldon, N.D., Barrenechea, J.F., Luque, F.J., Arche, A., Benito, M.I., 2012. Paleoecological and paleoenvironmental changes during the continental Middle-Late Permian transition at the SE Iberian Ranges, Spain. Glob. Planet. Chang. 94-95, 46-61. http://dx.doi.org/10.1016/j. gloplacha.2012.06.008.

Dercourt, J., Gaetani, M., Vrielynck, B., Barrier, E., Biju-Duval, B., Brunet, M.F., Cadet, J.P., Crasquin, S., Sandulescu, M., 2000. Peri-Tethys Atlas, Palaeogeographical Maps, CCGM/CGMW, Paris: 24 Maps and Explanatory Notes: I-XX, 1-269.

Erwin, D.H., 1994. The Permo-Triassic extinction. Nature 367, 231-236. http://dx.doi. org/10.1038/367231a0.

Fang, Q., Wu, H., Hinnov, L.A., Jing, X., Wang, X., Jiang, Q., 2015. Geologic evidence for chaotic behaviour of the planets and its constraints on the third-order eustatic sequences at the end of the Late Paleozoic Ice Age. Palaeogeogr. Palaeoclimatol. Palaeoecol. 440, 848-859. http://dx.doi.org/10.1016/j.palaeo.2015.10.014.

Gand, G., Durand, M., 2006. Tetrapod footprint ichno-associations from French Permian basins. Comparisons with other Euramerican ichnofaunas. In: Lucas, S.G., Cassinis, G., Schneider, J.W. (Eds.), Non-Marine Permian Biostratigraphy and Biochronology Geological Society of London Special Publication 265, London, pp. 157-177. http:// dx.doi.org/10.1144/GSL.SP.2006.265.01.07.

Gand, G., Garric, J., Demathieu, G.R.S., Ellenberger, P., 2000. La palichnofaune de vertébrés tétrapodes du Permien supérieur du Bassin de Lodève (Languedoc-France). Palaeovertebrata 29 (1), 1-82.

Gand, G., Garric, J., Schneider, J., Walter, H., Lapeyrie, J., Martin, C., Thiery, A., 2008. Notostraca trackways in Permian playa environments of the Lodève basin (France). J. Iber. Geol. 34 (1), 73-108. http://dx.doi.org/10.1002/adma.200802733.

Gascón, F., Gisbert, J., 1987. La evolución climática del Stephaniense, Pérmico y Buntsandstein del Pirineo catalán en base al estudio de paleosuelos. Cuadernos de Geología Ibérica. 11. pp. 97-114.

Gastaldo, R.A., Kamo, S.L., Neveling, J., Geissman, J.W., Bamford, M., Looy, C.V., 2015. Is the vertebrate-defined Permian-Triassic boundary in the Karoo Basin, South Africa, the terrestrial expression of the end-Permian marine event? Geology 43 (10), 939-942. http://dx.doi.org/10.1130/G37040.1.

Gibbs, M.T., Rees, P.M., Kutzbach, J.E., Ziegler, A.M., Behling, P.J., Rowley, D.B., 2002. Simulations of Permian climate and comparisons with climate-sensitive sediments. J. Geol. 110 (1), 33-55. http://dx.doi.org/10.1086/324204.

Gisbert, J., 1981. Estudio geológico-petrológico del Estefaniense-Pérmico de la Sierra del Cadí (Pirineo de Lérida): Diagénesis y sedimentología (Ph.D. Thesis). University of Zaragoza, Spain.

Gisbert, J., Martí, J., Gascón, F., 1985. Guía de la excursión al Stephaniense, Pérmico y Triásico inferior del Pirineo catalán. II Coloquio de estratigrafía y paleogeografía del Pérmico y Triásico de España. (79 pp.).

Gómez-Gras, D., Alonso-Zarza, A.M., 2003. Reworked calcretes: their significance in the reconstruction of alluvial sequences (Permian and Triassic, Minorca, Balearic Islands, Spain). Sediment. Geol. 158, 299-319. http://dx.doi.org/10.1016/S0037-0738(02) 00315-9.

Gretter, N., Ronchi, A., López-Gómez, J., Arche, A., De la Horra, R., Barrenechea, J.F., Lago, M., 2015. The Late Palaeozoic-Early Mesozoic from the Catalan Pyrenees (Spain): $60 \mathrm{Myr}$ of environmental evolution in the frame of the western peri-Tethyan palaeogeography. Earth Sci. Rev. 150, 679-708. http://dx.doi.org/10.1016/j. earscirev.2015.09.001.

Grice, K., Cao, C., Love, G.D., Böttcher, M.E., Twitchett, R.J., Grosjean, E., Summons, R.E., Turgeon, S.C., Dunning, W., Jin, Y., 2005. Photic zone euxinia during the Permian-Triassic superanoxic event. Science 307 (5710), 706-709. http://dx.doi. org/10.1126/science.1104323.

Gubin, Y.M., Golubev, V.K., Bulanov, V.V., Petuchov, S.V., 2003. Pareiasaurian tracks from the Upper Permian of Eastern Europe. Paleontol. J. 37 (5), 514-523.

Hartevelt, J.J.A., 1970. Geology of the upper Segre and Valira valleys, central Pyrenees, Andorra/Spain. Leidse. Geol. Meded. 45, 349-354.

Haubold, H., 1971. Ichnia Amphibiorum et Reptiliorum fossilium. In: Wellnhofer, P. (Ed.), Encyclopedia of Paleoherpetology 18. Fischer Verlag, Stuttgart and Portland (124 pp.).

Hiete, M., Berner, U., Heunisch, C., Röhling, H.-G., 2006. A high-resolution inorganic geochemical profile across the Zechstein-Buntsandstein boundary in the North German Basin. Z. Dtsch. Ges. Geowiss. 157 (1), 77-105. http://dx.doi.org/10.1127/ 1860-1804/2006/0157-0077.

Hofmann, A., Tourani, A., Gaupp, R., 2000. Cyclicity of Triassic to Lower Jurassic continental red beds of the Argana Valley, Morocco: implications for palaeoclimate and basin evolution. Palaeogeogr. Palaeoclimatol. Palaeoecol. 161, 229-266.

Kump, L.R., Pavlov, A., Arthur, M.A., 2005. Massive release of hydrogen sulphide to the surface ocean and atmosphere during intervals of oceanic anoxia. Geology 33 (5), 397-400. http://dx.doi.org/10.1130/G21295.1.

Kustatscher, E., Bernardi, M., Petti, F.M., Franz, M., van Konijnenburg-van Cittert, J.H.A., Kerp, H., 2017. Sea-level changes in the Lopingian (late Permian) of the northwestern Tethys and their effects on the terrestrial palaeoenvironments, biota and fossil preservation. Glob. Planet. Chang. 148, 166-180. http://dx.doi.org/10.1016/j. gloplacha.2016.12.006.

Kutzbach, J.E., Ziegler, A.M., 1993. Simulation of Late Permian climate and biomes with an atmosphere-ocean model: comparisons with observations. Philos. Trans. R. Soc. B 341, 327-340. http://dx.doi.org/10.1098/rstb.1993.0118.

Leonardi, G., 1987. Glossary and Manual of Tetrapod Footprint Palaeoichnology.
Departamento Nacional de Produção Mineral, Brasilia (117 pp.).

Li, M., Huang, C., Hinnov, L., Ogg, J., Chen, Z.-Q., Zhang, Y., 2016. Obliquity-forced climate during the Early Triassic hothouse in China. Geology 44 (8), 623-626. http:// dx.doi.org/10.1130/G37970.1.

Liebrecht, T., Fortuny, J., Galobart, À., Müller, J., Sander, P.M., 2017. A large, multipletooth-rowed captorhinid reptile (Amniota: Eureptilia) from the upper Permian of Mallorca (Balearic Islands, western Mediterranean). J. Vertebr. Paleontol. 37 (1), e1251936. http://dx.doi.org/10.1080/02724634.2017.1251936.

Linol, B., Bercovici, A., Bourquin, S., Diez, J.B., López-Gómez, J., Broutin, J., Durand, M., Villanueva-Amadoz, U., 2009. Late Permian to Middle Triassic correlations and palaeogeographical reconstructions in south-western European basins: new sedimentological data from Minorca (Balearic Islands, Spain). Sediment. Geol. 220, 77-94. http://dx.doi.org/10.1016/j.sedgeo.2009.06.003.

Looy, C.V., Ranks, S.L., Chaney, D.S., Sanchez, S., Steyer, J.-S., Smith, R.M.H., Sidor, C.A., Myers, T.S., Ide, O., Tabor, N.J., 2016. Biological and physical evidence for extreme seasonality in central Permian Pangea. Palaeogeogr. Palaeoclimatol. Palaeoecol. 451, 210-226. http://dx.doi.org/10.1016/j.palaeo.2016.02.016.

Marchetti, L., 2016. New occurrences of tetrapod ichnotaxa from the Permian Orobic Basin (Northern Italy) and critical discussion of the age of the ichnoassociation. Pap. Palaeontol. 2 (3), 363-386. http://dx.doi.org/10.1002/spp2.1045.

Martí, J., 1983. La formación volcánica estefaniense Erill Castell (Pirineo de Lérida). Acta Geol. Hisp. 18 (1), 27-33.

Marty, D., Strasser, A., Meyer, C.A., 2009. Formation and taphonomy of human footprints in microbial mats of present-day tidal-flat environments: implications for the study of fossil footprints. Ichnos 16, 127-142. http://dx.doi.org/10.1080/ 10420940802471027.

Mey, P.H.W., Nagtegaal, P.J.C., Roberti, K.J., Hartevelt, J.J.A., 1968. Lithostratigraphic subdivision of post-Variscan deposits in the South-Central Pyrenees, Spain. Leidse. Geol. Meded. 41, 221-228.

Meyer, K.M., Kump, L.R., 2008. Oceanic euxinia in earth history: causes and consequences. Annu. Rev. Earth Planet. Sci. 36, 251-288. http://dx.doi.org/10.1146/ annurev.earth.36.031207.124256.

Michaelsen, P., 2002. Mass extinction of peat-forming plants and the effect on fluvial styles across the Permian-Triassic boundary, northern Bowen Basin, Australia. Palaeogeogr. Palaeoclimatol. Palaeoecol. 179, 173-188.

Michel, L.A., Tabor, N.J., Montañez, I.P., Schmitz, M.D., Davydov, V.I., 2015. Chronostratigraphy and paleoclimatology of the lodève Basin, France: evidence for a pan-tropical aridification event across the carboniferous-permian boundary. Palaeogeogr. Palaeoclimatol. Palaeoecol. 430, 118-131. http://dx.doi.org/10.1016/ j.palaeo.2015.03.020.

Mujal, E., Gretter, N., Ronchi, A., López-Gómez, J., Falconnet, J., Diez, J.B., De la Horra, R., Bolet, A., Oms, O., Arche, A., Barrenechea, J.F., Steyer, J.-S., Fortuny, J., 2016a Constraining the Permian/Triassic transition in continental environments: stratigraphic and paleontological record from the Catalan Pyrenees (NE Iberian peninsula). Palaeogeogr. Palaeoclimatol. Palaeoecol. 445, 18-37. http://dx.doi.org/10.1016/j. palaeo.2015.12.008.

Mujal, E., Fortuny, J., Oms, O., Bolet, A., Galobart, À., Anadón, P., 2016b. Palaeoenvironmental reconstruction and early Permian ichnoassemblage from the NE Iberian Peninsula (Pyrenean Basin). Geol. Mag. 153 (4), 578-600. http://dx.doi.org/ 10.1017/S0016756815000576.

Mujal, E., Fortuny, J., Bolet, A., Oms, O., López, J.Á., 2017. An archosauromorph dominated ichnoassemblage in fluvial settings from the late Early Triassic of the Catalan Pyrenees (NE Iberian peninsula). PLoS One 12 (4), e0174693. http://dx.doi. org/10.1371/journal.pone.0174693.

Nagtegaal, P.J.C., 1969. Sedimentology, paleoclimatology, and diagenesis of postHercynian continental deposits in the south-central Pyrenees, Spain. Leidse. Geol. Meded. 42, 143-238.

Newell, A.J., Sennikov, A.G., Benton, M.J., Molostovskaya, I.I., Golubev, V.K., Minikh, A.V., Minikh, M.G., 2010. Disruption of playa-lacustrine depositional systems at the Permo-Triassic boundary: evidence from Vyazniki and Gorokhovets on the Russian Platform. 1. J. Geol. Soc. Lond. 167, 695-716. http://dx.doi.org/10.1144/001676492009-103.

Paillard, D., Labeyrie, L., Yiou, P., 1996. Macintosh program performs time-series analysis. Eos Trans. AGU 77 (39), 379. http://dx.doi.org/10.1029/96EO00259.

Parrish, J.T., Peterson, F., 1988. Wind directions predicted from global circulation models and wind directions determined from eolian sandstones of the western United Statesa comparison. Sediment. Geol. 56 (1-4), 261-282. http://dx.doi.org/10.1016/00370738(88)90056-5.

Payne, J.L., Clapham, M.E., 2012. End-permian mass extinction in the oceans: an ancient analog for the twenty-first century? Annu. Rev. Earth Planet. Sci. 40, 89-111. http:// dx.doi.org/10.1146/annurev-earth-042711-105329.

Pereira, M.F., Castro, A., Chichorro, M., Fernández, C., Díaz-Alvarado, J., Martí, J., Rodríguez, C., 2014. Chronological link between deep-seated processes in magma chambers and eruptions: permo-carboniferous magmatism in the core of Pangaea (Southern Pyrenees). Gondwana Res. 25 (1), 290-308. http://dx.doi.org/10.1016/j. gr.2013.03.009.

Remy, R.R., Ferrell, R.E., 1989. Distribution and origin of analcime in marginal lacustrine mudstones of the green river formation, south-central Uinta Basin, Utah. Clay Clay Miner. 37 (5), 419-432. http://dx.doi.org/10.1346/CCMN.1989.0370505.

Retallack, G.J., 1996. Early Triassic therapsid footprints from the Sydney Basin, Australia. Alcheringa 20, 301-314.

Retallack, G.J., 2013. Permian and Triassic greenhouse crises. Gondwana Res. 24, 90-103. http://dx.doi.org/10.1016/j.gr.2012.03.003.

Retallack, G.J., Seyedolali, A., Krull, E.S., Holser, W.T., Ambers, C.P., Kyte, F.T., 1998. Search for evidence of impact at the Permian-Triassic boundary in Antarctica and Australia. Geology 26 (11), 979-982. 
Retallack, G.J., Jahren, A.H., Sheldon, N.D., Chakrabarti, R., Metzger, C.A., Smith, R.M.H., 2005. The Permian-Triassic boundary in Antarctica. Antarct. Sci. 17 (2) 241-258. http://dx.doi.org/10.1017/S0954102005002658.

Retallack, G.J., Metzger, C.A., Greaver, T., Jahren, A.H., Smith, R.M.H., Sheldon, N.D., 2006. Middle-Late Permian mass extinction on land. Bull. Geol. Soc. Am. 118 (11-12), 1398-1411. http://dx.doi.org/10.1130/B26011.1.

Retallack, G.J., Sheldon, N.D., Carr, P.F., Fanning, M., Thompson, C.A., Williams, M.L., Jones, B.G., Hutton, A., 2011. Multiple Early Triassic greenhouse crises impeded recovery from Late Permian mass extinction. Palaeogeogr. Palaeoclimatol. Palaeoecol. 308 (1-2), 233-251. http://dx.doi.org/10.1016/j.palaeo.2010.09.022.

Rey, K., Amiot, R., Fourel, F., Rigaudier, T., Abdala, F., Day, M.O., Fernandez, V., Fluteau, F., France-Lanord, C., Rubidge, B.S., Smith, R.M., Viglietti, P.A., Zipfel, B., Lécuyer, C., 2016. Global climate perturbations during the Permo-Triassic mass extinctions recorded by continental tetrapods from South Africa. Gondwana Res. 37, 384-396. http://dx.doi.org/10.1016/j.gr.2015.09.008.

Robles, S., Llompart, C., 1987. Análisis paleogeográfico y consideraciones paleoicnológicas del Pérmico superior y Triásico inferior en la transversal del río Segre (Alt Urgell, Pirineo de Lérido). In: Cuadernos de Geología Ibérica. 11. pp. 115-130.

Roscher, M., Schneider, J.W., 2006. Permo-Carboniferous climate: early Pennsylvanian to Late Permian climate development of central Europe in a regional and global context. In: Lucas, S.G., Cassinis, G., Schneider, J.W. (Eds.), Non-Marine Permian Biostratigraphy and Biochronology. 265. Geological Society of London Special Publication 265, London, pp. 95-136. http://dx.doi.org/10.1144/GSL.SP.2006.265. 01.05 .

Roscher, M., Stordal, F., Svensen, H., 2011. The effect of global warming and global cooling on the distribution of the latest Permian climate zones. Palaeogeogr. Palaeoclimatol. Palaeoecol. 309 (3-4), 186-200. http://dx.doi.org/10.1016/j.palaeo. 2011.05.042.

Rothman, D.H., Fournier, G.P., French, K.L., Alm, E.J., Boyle, E.A., Cao, C., Summons, R.E., 2014. Methanogenic burst in the end-Permian carbon cycle. PNAS 111 (15), 5462-5467. http://dx.doi.org/10.1073/pnas.1318106111.

Saura, E., Teixell, A., 2006. Inversion of small basins: effects on structural variations a the leading edge of the Axial Zone antiformal stack (Southern Pyrenees, Spain). J. Struct. Geol. 28 (11), 1909-1920. http://dx.doi.org/10.1016/j.jsg.2006.06.005.

Schneider, J.W., Körner, F., Roscher, M., Kroner, U., 2006. Permian climate development in the northern peri-Tethys area - the Lodève basin, French Massif Central, compared in a European and global context. Palaeogeogr. Palaeoclimatol. Palaeoecol. 240 (1-2), 161-183. http://dx.doi.org/10.1016/j.palaeo.2006.03.057.

Scholze, F., Wang, Z., Kirscher, U., Kraft, J., Schneider, J.W., Götz, A.E., Joachimski, M.M., Bachtadse, V., 2017. A multistratigraphic approach to pinpoint the PermianTriassic boundary in continental deposits: the Zechstein-Lower Buntsandstein transition in Germany. Glob. Planet. Chang. 152, 129-151. http://dx.doi.org/10.1016/j gloplacha.2017.03.004.

Schulz, M., Mudelsee, M., 2002. REDFIT; estimating red-noise spectra directly from un evenly spaced paleoclimatic time series. Comput. Geosci. 28, 421-426.

Sheldon, N.D., Chakrabarti, R., Retallack, G.J., Smith, R.M.H., 2014. Constraining geochemical signatures on land from the Middle and Late Permian extinction events. Sedimentology 61, 1812-1829. http://dx.doi.org/10.1111/sed.12117.
Słowakiewicz, M., Kiersnowski, H., Wagner, R., 2009. Correlation of the Middle and Upper Permian marine and terrestrial sedimentary sequences in Polish, German, and USA Western Interior Basins with reference to global time markers. Palaeoworld 18 (2-3), 193-211. http://dx.doi.org/10.1016/j.palwor.2009.04.009.

Smith, R.M.H., Sidor, C.A., Tabor, N.J., Steyer, J.-S., 2015. Sedimentology and vertebrate taphonomy of the Moradi Formation of northern Niger: a Permian wet desert in the tropics of Pangaea. Palaeogeogr. Palaeoclimatol. Palaeoecol. 440, 128-141. http:// dx.doi.org/10.1016/j.palaeo.2015.08.032.

Speksnijder, A., 1985. Anatomy of a strike-slip fault controlled sedimentary basin, Permian of the Southern Pyrenees, Spain. Sediment. Geol. 44, 179-223.

Surkov, M.V., Benton, M.J., Twitchett, R.J., Tverdokhlebov, V.P., Newell, A.J., 2007. First occurrence of footprints of large therapsids from the Upper Permian of European Russia. Palaeontology 50 (3), 641-652.

Tabor, N.J., Montanez, I.P., 2002. Shifts in late Paleozoic atmospheric circulation over western equatorial Pangean: insights from pedogenic $\mathrm{d}^{18} \mathrm{O}$ compositions. Geology 30 (12), 1127-1130. http://dx.doi.org/10.1130/0091-7613(2002) $030<1127$ :SILPAC $>2.0$. CO; 2 .

Tabor, N.J., Smith, R.M.H., Steyer, J.-S., Sidor, C.A., Poulsen, C.J., 2011. The Permian Moradi Formation of northern Niger: Paleosol morphology, petrography and mineralogy. Palaeogeogr. Palaeoclimatol. Palaeoecol. 299, 200-213. http://dx.doi.org/10. 1016/j.palaeo.2010.11.002

Torsvik, T.H., Cocks, L.R.M., 2013. Gondwana from top to base in space and time. Gondwana Res. 24, 999-1030. http://dx.doi.org/10.1016/j.gr.2013.06.012.

Valentini, M., Conti, M.A., Mariotti, N., 2007. Lacertoid Footprints of the Upper Permian Arenaria di Val Gardena Formation (Northern Italy). Ichnos 14 (3-4), 193-218. http://dx.doi.org/10.1080/10420940601049974.

Valentini, M., Nicosia, U., Conti, M.A., 2009. A re-evaluation of pachypes, a pareiasaurian track from the late permian. In: Neues Jahrbuch Fur Geologie Und Palaontologie Abhandlungen. 251(1). pp. 71-94. http://dx.doi.org/10.1127/0077-7749/2009/ 0251-0071.

Voigt, S., Hminna, A., Saber, H., Schneider, J.W., Klein, H., 2010. Tetrapod footprints from the uppermost level of the Permian Ikakern Formation (Argana Basin, Western High Atlas, Morocco). J. Afr. Earth Sci. 57 (5), 470-478. http://dx.doi.org/10.1016/ j.jafrearsci.2009.12.003.

Ward, P.D., Montgomery, D.R., Smith, R., 2000. Altered river morphology in South Africa related to the Permian-Triassic extinction. Science 289, 1740-1743. http://dx.doi. org/10.1126/science.289.5485.1740.

Williams, M.L., Jones, B.G., Carr, P.F., 2012. Geochemical consequences of the PermianTriassic mass extinction in a non-marine succession, Sydney Basin, Australia. Chem. Geol. 326-327, 174-188. http://dx.doi.org/10.1016/j.chemgeo.2012.07.021.

Xu, G., Deconinck, J.-F., Feng, Q., Baudin, F., Pellenard, P., Shen, J., Bruneau, L., 2017. Clay mineralogical characteristics at the Permian-Triassic Shangsi section and their paleoenvironmental and/or paleoclimatic significance. Palaeogeogr. Palaeoclimatol. Palaeoecol. 474, 152-163. http://dx.doi.org/10.1016/j.palaeo.2016.07.036.

Zhang, H., Cao, C.-q., Liu, X.-1., Mu, L., Zheng, Q.-f., Liu, F., Xiang, L., Liu, L.-j., Shen, S.-z., 2016. The terrestrial end-Permian mass extinction in South China. Palaeogeogr. Palaeoclimatol. Palaeoecol. 448, 108-124. http://dx.doi.org/10.1016/j.palaeo.2015. 07.002 . 